\title{
ECONOMICS
}

\section{RECONSTRUCTING THE SAVINGS GLUT: THE GLOBAL IMPLICATIONS OF ASIAN EXCESS SAVING}

\author{
by \\ Vipin Arora \\ United States Energy Information \\ Washington DC \\ and \\ Rod Tyers \\ Business School \\ University of Western Australia \\ and \\ Ying Zhang \\ Business School \\ University of Western Australia
}




\title{
RECONSTRUCTING THE SAVINGS GLUT: THE GLOBAL IMPLICATIONS OF ASIAN EXCESS SAVING*,**
}

\author{
Vipin ARORA \\ United States Energy Information Administration \\ Washington DC \\ Rod TYERS \\ Business School \\ University of Western Australia, \\ Research School of Economics \\ Australian National University, and \\ Centre for Applied Macroeconomic Analysis (CAMA) \\ Crawford School of Government \\ Australian National University \\ Ying ZHANG \\ Business School \\ University of Western Australia \\ Also CAMA Working Paper 2014-02/20 \\ Centre for Applied Macroeconomic Analysis \\ Crawford School \\ Australian National University
}

Key words:

Savings glut, China, Japan, global natural rate

JEL Codes:

F42, F43, F47

\section{DISCUSSION PAPER 14.24}

Author best contact details:

Rod Tyers

Winthrop Professor of Economics

UWA Business School

Crawley, WA 6009

Australia

rod.tyers@uwa.edu.au

* Funding for the research described in this paper is from Australian Research Council Discovery Grant No. DP0879094. Useful discussions on the topic with Dong He, Bert Hoffman, Song Ligang, Paul Luk, Dai Mi, Peter Robertson and Wenlang Zhang are acknowledged, along with comments received at seminars on related papers at the China Center for Economic Research, Peking University and the Hong Kong Institute of Monetary Research.

** The analysis and conclusions expressed here are those of the authors and not necessarily those of the U.S.

Energy Information Administration. 


\begin{abstract}
East Asian, and primarily Chinese and Japanese, excess saving has been comparatively large and controversial since the 1980s. That it has contributed to the decline in the global "natural" rate of interest is consistent with Bernanke's much debated "savings glut” hypothesis for the decade after 1998, empirical explorations of which have proved unconvincing. In this paper it is argued that the comparatively integrated global market for long bonds is suggestive of trends in the "world" natural rate and that the longer term evidence supports a leading role for Asia's contribution to the expansion of ex ante global saving in explaining the declining trend in real long yields. Evidence is presented that trends in US 10 year bond yields are indeed representative of those in the "world" natural rate. The relationship between these yields and excess saving in China and Japan is then explored using a VECM that accounts for US monetary policy. The results support a negative long term relationship between 10 -year yields and the current account surpluses of China and Japan. Projections using the same model then suggest that a feasible range of future pathways for those current accounts could cause the path of long rates to deviate by 330 basis points over the next decade.
\end{abstract}




\section{Introduction}

The rise of China and other Asian, heretofore developing, economies since the 1980s has not only underwritten global economic performance but, by cheapening traded light manufactures and supplying substantial excess savings, it has demonstrably conferred on the developed regions terms of trade gains in both product and financial markets. The terms of trade gain transmitted financially is a consequence of the imbalance between production and consumption growth that has stemmed from the East Asian export-led growth model. Common to the growth experiences of Japan, Korea, Taiwan, Southeast Asia and, more recently, mainland China have been surges in growth that outpace permanent income and so result in high precautionary saving (Modigliani Cao 2004). Particular attention has been directed to East and Southeast Asian saving during the decade following the Asian financial crisis (AFC).

Bernanke (2005a and b) argues that savings and reserve accumulation were fostered in order to keep exchange rates from appreciating against the US dollar, with the indirect consequence of cheapening credit in advanced regions in the lead-up to the global financial crisis (GFC). This case has been commonly referred to as the "savings glut" hypothesis central to the work of Chinn and Ito (2007), Choi et al. (2008), Chinn et al. (2012) and Kehoe et al. (2012). ${ }^{1}$

Yet the "savings glut" hypothesis also has important detractors. Their focus is the implication that, prior to the GFC, cheap credit in the US and Europe was due to the savings glut and that this contributed to the bubble conditions in asset markets (Laibson and Mollerstrom 2010, Borio and Disyatat 2011 and Shin 2011). They note that surges in net US financial inflows and declines in yields were not coincident in this period and that other factors precipitated the GFC. Laibson and Mollerstrom see it as the bursting of a self-perpetuating property bubble; Borio and Disyatat see it, more particularly, as depending on the pattern of gross financial flows into and out of the US, with a particular focus on European flows that expanded substantially in the lead up to the GFC. This view is formalised by Shin, who notes large expansions in the balance sheets of key European banks in the decade post the EMU, their expanding and very substantial role in financial intermediation in the US market and the comparatively lax capital standards imposed on them by European regulators. It is this, says Shin, rather than the net financial inflow from China, Japan and OPEC, that gave rise to bubble-inflating credit.

While the waters are muddied with respect to the decade between the crises, the global effects of high saving in Asia extend over three decades. As emphasised by the World Bank (2013),

\footnotetext{
${ }^{1}$ Other dollar targeters, including the OPEC countries, are seen as also having contributed (Kodres and Warnock, 2006).
} 
of the addition to global GDP since 1980, measured in US dollars at current exchange rates, a third is due to Asian growth. At the same time Asian economies have contributed about half of the corresponding increment to global saving, with China alone contributing fully a third of the increment since 1990. Even before China’s recent surge, however, Asia was a major contributor to global saving growth. The shift in global growth toward high-saving Asia, which occurred in the 1980s, accelerated the rate at which the global savings supply curve shifted to the right. If the corresponding global investment demand curve shifted by less, which is suggested by Asian current account surpluses, there would have been a decline in the Wicksellian (1898) "natural” rate of interest at the global level.

In this paper we posit that the trend of the underlying natural rate of interest is reflected in the corresponding trends in long bond yields, a position we support by showing that the long bond markets of the advance regions are globally integrated. Consistent with the segmentation theory of the yield curve (Johnson et al. 2010), the results support the view of long rates as being not merely expectational extensions of short policy rates (Shiller et al. 1983, He and McCauley 2013). We then examine the behavioural links between Asian saving and long bond yields since the 1980s. While we agree with the critics of the savings glut hypothesis that the evidence for a link between the Asian saving growth and long yields during the decade between the crises is not strong, we find that the links are better supported by the long term data. If this is true, irrespective of the debate over the causes of the GFC, future changes in the pattern of East Asian growth and its saving rates have important implications for global financial markets and economic performance in the developed regions.

We investigate the nature of this interaction using a vector error correction model (VECM) that accounts for the impacts of changes in US monetary policy, and find support for a significant negative relationship between the current accounts of China and Japan and long yields. We then consider the likelihood of declines in excess saving in China and Japan, due to the ageing of their populations and changes to the sources of corporate saving due to further industrial reform. ${ }^{2}$ Projections using our model suggest that this will tighten global financial markets at a time when the US “taper” will be doing the same.

The following section reviews the macro literature on spill-overs from Asian growth and the savings glut hypothesis, concluding with a superficial case in support of the hypothesis over

\footnotetext{
2 The English language literature on reforms and future growth in these two important economies is large and diverse. See, for example, Lardy (2012) and Tyers (2013) on Chinese structural reforms and Taylor (2006), Fukao, K. (2010) and Tyers and Zhang (2011b) on reform and recovery in Japan.
} 
the three decades since the early 1980s. Section 3 then examines the extent to which long bond markets are globally integrated, compared with shorter maturities, and are therefore representative of movements in the underlying natural rate. Section 4 presents more rigorous testing of the savings glut hypothesis, that is supportive of negative links between Asian saving and long rates and Section 5 examines the implications of these results for global markets in the post-transition era. Conclusions are offered in Section 6.

\section{Asian Macro Spill-Overs}

There is a substantial literature on the external effects of Asian expansion since the 1980s. South Asian growth has been comparatively self-contained while that in East and Southeast Asia has been characterised by imbalances between the paths of output and consumption and very large expansions in trade dependence and financial flows. The story begins with Japan in the 1960s and proceeds to the "newly industrialising countries" of the 1970s and 80s (Korea, Taiwan, Hong Kong and Singapore) and to the surges in growth in Southeast Asia prior to the Asian Financial Crisis (AFC). It concludes with the extraordinary rise of mainland China since then. The debates concerning the global effects of this East Asian rise begin with trade and labour market effects arising from the early specialisation in light manufactures, leading to comparative specialisation in production, requiring the rapid growth of trade and causing substantial changes in the terms of trade with advanced economies. The first period of interest was the 1980s, which saw a comparative deterioration in the labour market performance of low-skill US and European workers. An extensive survey, grounded in the Stolper-Samuelson Theorem, was offered early on by Wood (1994). The subsequent literature broadened and can be thought of as divided amongst labour and global general equilibrium analysis, with the general equilibrium studies employing primarily neoclassical models and emphasising terms of trade effects while largely disregarding current account imbalances. ${ }^{3}$

Here we focus on the associated macroeconomic, financial “imbalances”, literature, which grew most rapidly after the AFC. Its emphasis on exchange rate policy and excess saving spawned the savings glut hypothesis. A more recent literature examines the period since the GFC, during which both Japan and China have embarked on new avenues to future growth, the external implications of which differ from the past. We consider the savings glut hypothesis first.

\footnotetext{
${ }^{3}$ For a review of labour and general equilibrium studies, see Tyers (2014).
} 


\subsection{The Savings Glut Hypothesis}

The early applied macroeconomic assessments of Asian, and particularly China's, growth are divided. On the one hand there are those seeing a sustainable global order with export-oriented growth and quasi-fixed exchange rate regimes at the expanding "periphery” (Dooley et al. 2003, 2005, 2011). On the other, many have worried about the imbalances between consumption and production in the East Asian growth model and the "upstream" financial flows that stem from them. These arise, in part, because growth outstrips adjustments to “permanent incomes” bolstering saving, creating substantial current account surpluses and hence "upstream” financial flows. ${ }^{4}$ Critics of China’s growth strategy have attributed its contribution to these upstream financial flows to capital market distortions, exchange rate management and myriad other interventions by the all-pervasive Chinese state to confer unfair advantage on Chinese firms and to raise exports and investment at the expense of household consumption. $^{5}$

This, primarily US, literature parallels in many ways that of the 1980s that saw the Japanese economy as a threat for similar reasons (McKinnon 2004, 2006, Ito 2009). It is well understood that Japanese monetary policy had tended to target the Yen-dollar rate and that the Bank of Japan came under substantial pressure from the US for Yen appreciation. ${ }^{6}$ The Plaza Accord is the most famous instance, though it was followed by the formalisation of this pressure via the US Exchange Rates and International Economic Policy Coordination Act of 1988, which was designed to address competition from Japan. The modern incarnation is focussed on China, particularly in the decade between the Asian and global financial crises, when saving increased in East and Southeast Asia broadly and substantial official foreign reserves were accumulated. ${ }^{7}$ Bernanke (2005 a and b, 2011) suggests that the resulting "savings glut” cheapened credit in the US and contributed to its property bubble in the lead up to the GFC. This position, directed as it is to the decade between the crises, has been effectively opposed on empirical grounds and an alternative explanation for cheap pre-GFC

\footnotetext{
${ }^{4}$ These upstream flows are central to a substantial literature that includes Caballero et al. (2008), Caballero (2009), Chinn and Ito (2007), Choi et al. (2008), Chinn et al (2012), Eichengreen (2004) and Lee and McKibbin (2007).

${ }^{5}$ The American literature critical of China's macroeconomic policies is also extensive. Krugman (2010) declares that "China is making all of us poorer". The US macroeconomic position is put in more detail by, amongst others, Lardy (2006, 2012) and Bergsten et al. (2008). Similar advocacy of policy-induced "balance” in China's growth can be found, still more formally, in Blanchard and Giavazzi (2006), while it is also recognised that some of the US reaction to Chinese growth is mercantilist (Ito 2009).

${ }^{6}$ See Henning (2008), especially Chapters 3-4.

${ }^{7}$ While China's reserve accumulation was idiosyncratic to its capital controls and high saving, other developing Asian countries accumulated reserves to maintain Yuan parity since China was both an export competitor and a growing destination for exports of intermediates (Tyers and Zhang 2011a).
} 
credit proposed that depends on the size and composition of gross financial flows between the US and Europe and their different approaches to bank regulation (Laibson and Mollerstrom 2010, Borio and Disyatat 2011 and Shin 2011).

Yet the global effects of high saving in Asia extend to the three decades since the early 1980s. The central idea behind this is illustrated in Figure 1. High (primarily) Asian saving causes an ex ante rise in global saving (AC) that is larger than the corresponding ex ante rise in global investment demand $(\mathrm{AB})$. The underlying Wicksellian natural rate of interest falls and the observed rise in both saving and investment is AD. Verifying this empirically confronts two problems. First, we cannot observe shifts in ex ante saving or investment and, second, neither can we directly observe the natural rate of interest. Consider these in turn.

Some indication of ex ante changes is available from a regional disaggregation. Since 1980, a major contribution to global growth has been from high-saving Asian economies that have tended to have current account surpluses, suggesting that saving supply has outstripped investment demand in these economies and, therefore, globally. The numbers are indicated in Table 1, which shows that, of the post-1980 addition to global GDP, measured in US dollars at current exchange rates, a third is due to Asian growth. But the corresponding Asian contribution to global saving is about half, with China contributing fully a third of the increment after 1990. Even before China's recent surge, the whole of Asia had saving that ran well ahead of the global level, as Figure 2 shows. This is evidence that the shift in global growth toward high-saving Asia, which occurred in the 1980s, accelerated the rate at which the global savings supply curve shifted to the right. The smaller ex ante shift in global investment demand is suggested both by Asia's current account surpluses, indicating that their saving exceeds their investment, and by the tendency, in expanding economies, for investment and output to grow at the same pace. All of this points to a declining trend in the natural rate of interest globally.

Turning to the problem of observing the natural rate of interest, a solution arises from the debate over the behaviour that underlies the yield curve. The prevailing theory posits that rates at all maturities stem ultimately from short policy rates imposed by central banks. Long rates exceed short because of inflation expectations and term risk premia. According to this theory, the natural rate is only observable if long rates just happen to converge on it across countries, which might occur by chance or via coordinated and well founded monetary policy by central banks (Borio and Disyatat 2011). But this theory ignores financial transaction costs and the vagaries of expectation formation that have come under attack along with the wider efficient 
markets hypothesis (Shiller et al. 1983). There are in fact frequently large differences between long and short rates, which would be arbitraged down to inter-temporal risk premia if a sequence of short contracts were no more expensive than a single long one. But this is not the case and it is observed that trading at the short end has differed markedly from that at the long end.

The long market tends to match savers to investors with portfolios dominated by long instruments while (at least under conventional monetary policy) the short market serves monetary policy and country-specific financial services. This suggests that the trend in long rates is suggestive of the change in the underlying global natural rate. Beyond Johnson's (2008) explanatory models of the segmentation theory, He and McCauley (2013) find empirical evidence of "imperfect substitutability along the yield curve" and use it to explore monetary policy spill-over effects, which they see as enlarged by the global integration of long bond markets. Ito (2013: 8) offers support for this view. He argues that as a result of financial globalisation, domestic financial markets are more susceptible to international factors and that this tends to decouple short-term and long-term rates. Consistent with Bernanke (2005a and b), he concludes that the long-term interest rate is tied down by global saving imbalances and hence reflects the natural rate of interest. This reasoning, and that of Rey (2013), both imply that, when there is free capital mobility, there is inter-regional arbitrage going at the long end of the yield curve whereas the short end of the yield curve is controlled by monetary authorities, serving primarily domestic financial interests.

Support for this international arbitrage at the long end is suggested by the time paths of 10 year yields in Figure 3, which show more integration than the corresponding paths of three month yields in Figure 4. We will return in Section 3 to a more formal examination of the comparative integration of the markets for long bonds. In the meantime, if it is true that the long yields suggest trends in the underlying natural rate, the rise in Asian saving is a possible explanation for the persistent downward trend in long term bond rates since the 1980s that is also apparent from Figure 3. ${ }^{8}$ A simple inverse relationship is certainly apparent as between real long yields and the real sum of Japan's and China's current account surpluses, as shown in Figure $5 .^{9}$ If this link is fundamental, irrespective of the debate over the causes of the GFC, the

\footnotetext{
${ }^{8}$ The separation of the series for Japan is associated with its long term current account surplus and the major Yen appreciation shocks of the late 1980s and early 1990s, which established a negative risk premium amongst Japanese savers (Goyal and McKinnon 2003). In all regions, inflation rates were low throughout the period shown in the figure and so the trend of nominal long rates reflects that of corresponding real rates.

${ }^{9}$ The downward trend in real long rates survives sophisticated treatment of inflation, via the use of inflation indexed bonds, in the analysis by King and Low (2014).
} 
impending changes, particularly in the pattern of Chinese growth and its saving rates, have important implications for global financial markets and economic performance in the developed regions. We turn now to these likely changes.

\subsection{Asian Transitions and their Effects on Excess Saving}

The two most internationally significant post-GFC transitions under way in Asia are those in Japan and China. China's excess saving is greater than Japan's and, indeed, it remains the largest of any single country. Financial spill-overs from the Chinese transition are therefore more likely to have significant international effects. Although China's rate of expansion during its three decades of reform has been spectacular, it is only in the last decade that its economic size has paralleled those of the US, the EU and Japan. China's exports have grown especially rapidly since the turn of the century and now dominate world trade in light manufactures. ${ }^{10}$ As of 2011 its unadjusted share of global GDP was greater than Japan's and its shares of global exports, saving and investment were larger than those of the US and close to those of the EU (Table 2).

Although China remains much poorer than Japan ${ }^{11}$ its significance stems from its huge population. This contrast notwithstanding, both economies face transitions with common elements. In the coming decade, both Japan and China must deal with demographic contractions and changes to their sources of further growth. We consider each transition in turn.

\section{The Japanese Transition}

After a period of strong, catch-up, growth to the 1970s, Japanese economic performance was impaired by the energy crisis of that period and it slowed temporarily. By the end of that decade, however, it had recovered. Comparatively strong returned through the end of the 1980s but the asset bubble brought on by currency commitments associated with the Plaza Accord, combined with what hindsight reveals as subsequent policy errors, brought forth a period of comparative stagnation. ${ }^{12}$ Very large real appreciations in the late 80 s and early 1990s did not help and these led to substantial aversion to foreign exchange risk amongst

\footnotetext{
${ }^{10}$ According to trade data from data.worldbank.org, Chinese manufactured exports now sum to more than a third of the collective manufactured imports of the US, the EU and Japan, to which level growth has been extraordinary since 2001, when China's share was only seven per cent.

${ }^{11}$ According to Penn World Tables data for 2010, the exchange rate weighted level of real GDP per capita for China was less than 20 per cent of the corresponding value for the US, while Japan's and Korea's were 75 and 65 per cent, respectively.

12 There is an immense English language literature on Japan's stagnation and many theories as to causes and the ingredients of recovery. See Hoshi and Kashyap (2004), Horioka (2006) and Tyers (2012).
} 
Japan’s average savers, keeping yields on home assets comparatively low (Figure 3). This notwithstanding, investment leaked to high returns in China during the stagnation period, leading to poor performance in key sectors, particularly services, even while a few efficient export-oriented industries continued to thrive.

At the same time, Japan's fertility rate plummeted and its population is now declining. The associated ageing of both population and workforce have greatly reduced average household saving rates (Horioka and Terada-Hagiwara 2012) and this is leading to a downward trend in Japan's current account surplus. Manufacturing, which is labour intensive on average, will not be the lead sector in any recovery. This must come from industrial and services policy and regulatory reforms (Fukao, K. 2010) as well as more fundamental reforms, including to its taxation system. Japan's taxation system not only contributes to its structural budget deficits but also to its high rate of corporate saving. Impending reforms under the current Japanese government could see changes that lead to higher dividend payouts and reduced corporate saving, further reducing its current account position (Fukao, M. 2010). The demographic contraction, in addition to the most urgent industrial and regulatory reforms, is therefore likely to continue the trend of declining excess saving in Japan.

\section{China's transition}

Looking forward, notwithstanding China's comparative poverty, there is not the scope for the rest of the world to absorb export growth from China at historical rates. Moreover, there has been an accelerated rise in Chinese labour costs, foreshadowing a Lewis "turning point”", which is associated with the depletion of mobile labour in rural areas and a nation-wide demographic contraction stemming from China’s “one child” policy. Superficially, it would seem that a switch from export-oriented to inward-focussed growth should be possible, just by sustaining high investment and substituting consumption for exports. But this has been problematic because the growth to date has emphasised light manufacturing while China's growing middle class demands quality products and services that are as yet poorly represented in its production basket. To diversify China’s output toward these products requires major

\footnotetext{
${ }^{13}$ The timing of China's Lewis turning point is a subject of controversy, as suggested by the contrasts between the views expressed by: Cai (2010), Garnaut (2010) and Golley and Meng (2011), which offer just a sampling of a substantial literature. There is, however, little doubt that the turning point is on its way, even if there is no agreement as to whether recent real wage rises suggest its presence.
} 
reform of its heavy manufacturing and services sectors and investment in associated human capital. $^{14}$

Yet there is potential for substantial new growth from domestic sources. This stems, in particular, from the extension of industrial reforms into hitherto protected heavy manufacturing and services industries, where reductions in costs and prices could have major stimulatory effects on the economy as a whole. Such reforms include further pure privatisation, the fragmentation of state-owned enterprises to induce more competitive pricing, price cap regulation and greater access to services and heavy manufacturing by foreign investors. Oligopoly rents earned in these sectors are linked to corporate saving (Kuijs 2006, Song et al. 2011), which was last measured in the region of a fifth of GDP. Industry policy reforms that foster further privatisation, or that otherwise reduce oligopoly rents, are readily shown to reduce the aggregate level of Chinese saving by amounts sufficient to eliminate its current account surplus (Tyers 2013).

\section{Chinese excess saving}

National saving includes that by households, corporations and government. Savings that exceed the value of domestic private and public investment ("excess savings") result in the net acquisition of foreign assets and they are measured by the current account surplus:

$$
C A=S_{H H}+S_{C}+(T-G)-I=S_{D}-I=\Delta R-F I_{\text {Inward }}+F I_{\text {Outward }}=X-M+N
$$

Here $S_{H H}$ is household saving, $S_{C}$ is corporate saving, $(T-G)$ is government saving or the fiscal surplus, $S_{D}$ is total domestic saving, $I$ is investment (including public investment), $\Delta R$ is official foreign reserve accumulation, $C A$ is the current account balance and $N$ is net foreign factor income. ${ }^{15}$ FI signifies foreign investment, inflows or outflows. In China's case these terms are dominated by FDI since cross-border portfolio investments are restricted by its capital controls (Ma and McCauley 2007). Thus, to explore the implications for external accounts we must consider changes to household saving, corporate saving and government saving and compare these with changes in investment.

Household saving

\footnotetext{
${ }^{14}$ For a discussion of the institutional and industrial reform agenda and its difficulty, see for example Riedel (2011) and Deer and Song (2012).

${ }^{15}$ This identity is readily obtained by combining the expenditure identity, $Y=C+I+G+X$ - $M$ with the disposal identity for GNP, $Y+N=C+T+S$, where $S=S_{H H}+S_{C}$.
} 
The pattern and time trend of household saving in China and other Asian economies is analysed by Horioka and Wan (2007) and Horioka and Terada-Hagiwara (2012). They suggest that China is in the declining phase; a point with which Yang (2012) agrees, citing a range of mainly social and trade policy reforms that will see reduced incentives for household saving many of which are stated priorities of the new Chinese government. Moreover, recent studies question China's official statistics on consumption expenditure, suggesting that it is larger and growing more quickly than indicated (Ma and Yi 2010). If the weighted average of consumption-related retail and services sales growth is used to project the consumption share of GDP (Huang et al. 2012) the results suggest that the consumption share of GDP climbed from 49 to 54 per cent during 2008-2010, while China’s NBS has it falling from 48 to 47 per cent. ${ }^{16}$ Thus, there is much to suggest a declining path for China's household saving rate. ${ }^{17}$

\section{Corporate saving}

National accounts "flow of funds" data show corporate saving to have been fairly stable at about a fifth of GDP through 2009. In the period since, and looking forward, changes in total corporate saving might be anticipated for three reasons. First, to the extent that slower global growth since the GFC has affected profitability in the state sector, corporate savings might be expected to have also declined in recent years. Second, on-going industrial policy reforms, which have allowed substantial expansion in the share of private firms in the economy, are likely to have reduced oligopoly rents. Finally, financial development and the integration of formal and informal financial markets across the country have been proceeding apace. With more options and more security in the management of funds, it might be expected that the trend of corporate saving would be downward.

\section{Government saving}

Since the implementation of China's tax law in 1994, the domestic economy has gradually integrated, with an increasing share of economic activity taking place in the "formal sector".

\footnotetext{
${ }^{16}$ Huang et al. start with the official consumption share in 2000 and derive the GDP shares in remaining years using real GDP growth and their estimated consumption growth rates. Using similar data, Garner and Qiao (2013) suggest that Chinese consumption expenditure is officially underestimated by US\$ 1.6 trillion, also concluding that its GDP share is expanding.

${ }^{17}$ Opposing voices include Wei and Zhang (2011) and Wen (2011). Wei and Zhang identify a link between saving and entrepreneurship effort on the one hand and China's increasingly inflated sex ratio on the other. The coincidence of son preference and sexual selection technology has seen a rise in the number of unmatched men and increasingly competitive behaviour by families with sons. Debate continues about the strength of this force for higher saving against those associated with policy reforms in the education, health and retirement insurance industries. Wen, on the other hand, employs a model of rapid growth with constant proportional idiosyncratic risk, following Modigliani and Cao (2004), to conclude that saving will continue to rise with income per capita. The assumption of constant proportional risk is a strong one, however, in the face of social reforms to health and retirement systems.
} 
This has meant that central government tax revenue has grown steeply, at a rate that is notably faster than GDP. ${ }^{18}$ Along with this, central government financial surpluses have expanded continuously. At the same time, however, domestic commercial banks have lent extensively to SOEs and provincial governments, where in effect, debt has been underwritten centrally. Since the onset of the GFC, there has been an expansion in the share directed to provincial governments to finance local public investment. ${ }^{19}$ As shown in Figure 6, this has grown significantly since 2002 and it accelerated with the onset of the GFC and the government's plan to increase public works expenditure when export demand fell away temporarily. After 2007, the sum of the provincial deficits exceeded the central surplus, leading to a return to overall deficits with magnitudes expanding to unprecedented levels. Thus, government saving is also shifting in the negative direction in the post-GFC years.

Excess saving relative to investment

The above discussions lead us to expect a declining trend in China's total domestic saving rate though even where this is not yet fully represented in the official statistics, which thus far show only a slight decline since 2010. Since then, however, total (private and public) investment has risen to nearly half of GDP. ${ }^{20}$ The investment change has been the primary driver of the declining trend in China’s official current account surplus since 2010. This said, China's surplus remained the single largest across individual countries in $2012 .^{21}$

Looking ahead, it is difficult to imagine a higher rate of investment without the prospect of increasingly wasteful projects (Singh et al. 2013). Current financial conditions in China are dominated by the indebtedness of provincial governments (Zhang and Barnett 2014) and so are not consistent with a continuation of this surge in public investment. Thus, we expect home saving and investment to decline and future excess saving to depend on the differences between their rates of decline. The comparative prominence of government activity is expected to continue in China, however, and we see declines in household and corporate saving as the least uncertain of the elements of China's current account.

New roles for private financial flows are the wildcard:

\footnotetext{
${ }^{18}$ According to China's NBS Statistical Yearbook (2012), central government revenue has expanded its share of nominal GDP from 10\% in 1994 to 23\% in 2012.

${ }^{19}$ This is notwithstanding central government sharing of national revenue with the provinces at a 50-50 rate in 2011.

${ }^{20}$ In the medium term, at least, this has confirmed the prediction by Lee and McKibbin (2007) that investment would contribute substantially to China's "rebalancing”.

${ }^{21}$ IMF, IFS Database.
} 
Private flows on the capital account will also be influential - the inward and outward private foreign investment terms in (1). First, China's commitment to the internationalisation of the renminbi and toward capital account opening will lead to greatly expanded private holdings of foreign financial assets in both directions, though there is no suggestion that it will greatly affect the level and growth rate of net flows (He and Luk 2013). The empirical analysis by He et al. (2012) envisions a trend toward trade balance, offset in the current account by higher yields on foreign (newly private) holdings. Second, the effect on private flows of the winding down of unconventional monetary policy in the US could be substantial in the short term. This is likely to stem net private flows out of the US and into the region and therefore have a temporary supporting influence on the levels of Asian current accounts (Burns et al. 2014). Yet financial flows into and out of China will depend most on changes in Chinese conditions. We therefore expect continued decline in the average Chinese saving rate as the most likely core of future changes in its current account. The trend toward less excess saving is the most likely future course, not just because this is the apparent path since 2010 but also considering the trend toward financial deepening, the prospect of further social and industrial reform and the mounting evidence that consumption expenditure is growing faster than officially estimated.

\section{Long Bond Markets and the Natural Rate}

As indicated in the previous section, if we can show that long bond markets are more integrated between advanced regions than their short maturity counterparts, this supports the yield curve segmentation hypothesis, indicating that they are suggestive of the underlying natural rate of interest. More specifically, we seek to confirm that the US long rate is representative of long rates in other advanced regions and hence of the natural rate. Three approaches are taken to bond market integration across regions. For all, we compare integration measures for 10 year bonds against those for 3-month bonds. First, we test for cointegration of the level series for bond yields to identify common trends. Then we examine the extent to which departures from the trends in yields are correlated across regions and how these correlations have changed with time. Finally, we examine changes through time in the standard deviations of residuals from log-linear trends. 


\subsection{Co-integration}

As is suggested by Figure 3 and Figure 4, unit root tests (Table 3) show that the series of both long-term and short-term yields are non-stationary. For the long-term series, two lags are suggested unanimously by the AIC, HQIC and SBIC in lag-order selection tests (Appendix1, Table A.1). But for short-term rates there is no unanimity. Eight lags are suggested by the AIC, while the HQIC and SBIC both point to two lags. We choose to proceed with two lags, bearing in mind the conclusion of Lutkepohl (2006), who shows that the HQIC and SBIC provide more consistent estimates of the lag-order than AIC, which tends to overestimate the number of lags even with an infinite sample.

A standard Johansen co-integration test is then employed to seek out the existence of long-term relationships among the interest rates. The test outcomes depend on the trace statistic, the maximum eigenvalue and the information-criterion (IC). For long rates, all tests confirm cointegration, as indicated in Table 5. By contrast, the statistics in Table 5 are unanimous in suggesting that there are no co-integrating relationships among short-term rates. This offers the first strong evidence of comparative integration across the 10 year, relative to the 3 -month bond markets of the advanced economies.

\subsection{Correlations between deviations from trend}

To examine the correlations between deviations from trend over time, we split our sample into three periods bounded by the Asian and global financial crisis years: 1990-1997, 1998-2007 and 2008-2013. The full correlation matrices of concurrent proportional deviations from loglinear trend are reported in Appendix 1 while, for each period and duration, the key column linking the other rates to the US is presented in Table 7. For the long-term interest rate, these deviations from trend have tended to become more correlated through time. Indeed, these correlations with US rates have become larger on average since the GFC. By comparison, short rates, though positively correlated, appear much less inter-related than long rates, particularly in 1990-1997 and in the post-GFC era. This is consistent with view of short rates as being the instruments of region-specific monetary policy that is responding to business cycles that are not harmonised across regions.

\subsection{Standard Deviations of Proportional Departures from Trend}

Here standard deviations are taken of concurrent departures from region-specific log-linear trends. These are plotted in Figure 7. They show that the dispersion of short rates has increased through time while the trend in the dispersion of 10 year rates is flat. Moreover, the 
dispersion of short rates is consistently larger than for long rates by a factor of three, on average. All three approaches to the two sets of interest rate series are thus consistent in suggesting greater integration across regions at the long end of the yield curve. This pattern could only be consistent with a purely expectations driven yield curve by coincidence or by an unlikely combination of design by central banks and precise expectations formation by the private sector. We conclude that the weight of probabilities supports our use of the US long rate as a proxy for the underlying natural rate of interest at a global level.

\section{VECMs Linking Asian Excess Saving to Long Bond Yields}

Our conclusion that the trend and variations in the US 10 year rate reflect those of the natural rate enables us to consider whether Asian savings is able to account for at least some of the observed trend in US long bond yields. The decline in global real rates has occurred over decades and so our econometric specification explores the long-run relationship between Asian savings, global real interest rates and the effects on these of US monetary policy. After describing the data and confirming the existence of a long-run relationship between the variables, we construct a three variable VECM.

\subsection{Data Details, Unit Root Tests, and Summary Statistics}

We use three different quarterly data series in our analysis over the period from 1980 through 2013Q2: U.S. 10 year real interest rates, the sum of the Chinese and Japanese current account balances and, as a measure of monetary expansion (bond buying) in the US, the assets of the US Federal Reserve. These three series are plotted in Figure 8. Our behavioural perspective is that the long rise in Asian current account surpluses was active in causing the natural rate to fall until the GFC. Thereafter, Asian surpluses declined, reducing the excess Asian demand for the advanced regions' long bonds. Other things equal, this would have brought an end to the declining trend in yields. But US unconventional monetary policy then took over, raising global demand for long bonds considerably and ensuring that yields continued on their downward trend. The sources for the series are detailed in Appendix 2.

Three different tests for unit roots indicate that both series are I(1). Both the Augmented Dickey-Fuller (ADF) and the Ng and Perron (NP) tests are unable to reject the existence of a unit root in any of these series, while the Kwiatkowski, Phillips, Schmidt, and Shin (KPSS) test is able to reject stationarity, all at the $99 \%$ level of confidence. Although the U.S. Census Bureau's combined test for the presence of seasonality does not reveal an identifiable seasonal 
pattern in the series over the sample period, individual tests of moving seasonality cannot be rejected. Therefore annual differences are appropriate in examining the summary statistics displayed in Table 7.

Annual changes in the real current account balance of China and Japan have grown slightly over the sample period, while those in the real interest rate have fallen. The current account and real interest rate series display substantial volatility as compared with their means, with the current account over 18 times more volatile than the mean and the real interest rate over 28 times larger. The Fed assets series is nearly 2.5 times more volatile than the mean. The real current account series is also negatively skewed, indicating that the distribution of values over the sample is concentrated on the right-hand side, while the real interest rate has a positive skew and a distribution concentrated on the left-hand side, and Fed assets have a positive skew. All three series have positive kurtosis, meaning their distributions are narrower than that of the normal.

\subsection{Preliminary Testing}

We begin consideration of the relationship between the real current account balance and the real interest rate by testing whether changes in one of the series are able to predict changes in the other (Granger Causality). The tests are conducted using a VAR model and two structural dummy variables, one for China's WTO accession in 2001 and the other for the GFC. ${ }^{22}$ The tests indicate joint determination; that is, annual changes in either variable are able to predict changes in the other. This both confirms the existence of a relationship in differences, and also suggests that the long-run relationship should be modeled using a VECM.

In order to use the VECM, we next test for a long-run relationship between the levels of the real current account balance, the real interest rate and Fed assets, using the Johansen cointegration test. As with the Granger Causality tests, two structural dummies are included, one for China's WTO accession in 2001 and the other for the GFC, both of which are exogenous variables, as are various seasonal dummies, and the lag length is 5 quarters. ${ }^{23}$ The results suggest one co-integrating relationship between these variables over the sample period. The result is robust to using up to three more or three less lags in the testing specification.

\footnotetext{
${ }^{22}$ A lag length of 5 is chosen based on the HQIC and SBIC.

${ }^{23}$ As before, a lag length of 5 is chosen based on the HQIC and SBIC.
} 


\subsection{The VECM Specification}

Given that the tests indicate a long-run relationship between the variables we can move to specification of the VECM. Conceptually, this type of model assumes that a long-run (cointegrating) relationship exists between the variables, but that there are also short-run deviations around this relationship. The right-hand side of each equation in a VECM therefore has a co-integrating term, where the variables are specified in levels, and multiple short-run terms where the variables are in differences. Our current model is specified as:

$$
\begin{aligned}
\Delta r_{t}= & \alpha^{r}\left[r_{t-1}-\gamma C A_{t-1}-\phi F A_{t-1}-c\right]+\sum_{i=1}^{5} \beta_{i}^{r} \Delta r_{t-i}+\sum_{i=1}^{5} \theta_{i}^{r} \Delta C A_{t-i}+\sum_{i=1}^{5} \lambda_{i}^{r} \Delta F A_{t-i} \\
+ & \sum_{j=1}^{3} \delta_{j}^{r} S_{j}+\mu^{r} D^{2002}+\rho^{r} D^{G F C}+c^{r} \\
\Delta C A_{t}= & \alpha^{C A}\left[r_{t-1}-\gamma C A_{t-1}-\phi F A_{t-1}-c\right]+\sum_{i=1}^{5} \beta_{i}^{C A} \Delta r_{t-i}+\sum_{i=1}^{5} \theta_{i}^{C A} \Delta C A_{t-i}+\sum_{i=1}^{5} \lambda_{i}^{C A} \Delta F A_{t-i} \\
& +\sum_{j=1}^{3} \delta_{j}^{C A} S_{j}+\mu^{r} D^{2002}+\rho^{r} D^{G F C}+c^{C A} \\
\Delta F A_{t}= & \alpha^{F A}\left[r_{t-1}-\gamma C A_{t-1}-\phi F A_{t-1}-c\right]+\sum_{i=1}^{5} \beta_{i}^{F A} \Delta r_{t-i}+\sum_{i=1}^{5} \theta_{i}^{F A} \Delta C A_{t-i}+\sum_{i=1}^{5} \lambda_{i}^{F A} \Delta F A_{t-i} \\
& +\sum_{j=1}^{3} \delta_{j}^{F A} S_{j}+\mu^{F A} D^{2002}+\rho^{F A} D^{G F C}+c^{F A}
\end{aligned}
$$

Here, the $\Delta$ corresponds to a quarterly difference, the $S_{j}$ s are seasonal, and the Ds post-2001 and post-2007 dummy variables. The former is a proxy for the effects of China's accession to the WTO while the latter proxies transition to unconventional monetary policy, which saw the US Fed purchasing long instruments and therefore directly suppressing long rates. The longrun relationship is summarized by the term in parentheses, $\left[r_{t-1}-\gamma C A_{t-1}-\phi F A_{t-1}-c\right]$, while the short-run responses are captured in the differenced terms. Notice that the variables in the longrun relationship are lagged only one period, and are in levels, whereas the differenced terms have an arbitrary number of lags (5 in the equation).

The $\beta, \theta$ and $\lambda$ are short-run coefficients, and the $\gamma$ and $\phi$ are long-run coefficients. The longrun coefficient on the $r$ variable in the long-run relationship is normalized to unity. The final coefficient, $\alpha$, is often called the adjustment parameter. This value governs the magnitude of the response of the dependent variable to any deviations from the long-run relationship, as reflected in the co-integrating relationship in parentheses. The long-run coefficients, $\gamma$ and $\phi$, and the adjustment parameter, $\alpha$, are particularly important for the current analysis. The signs 
and statistical significance of both parameters govern the direction and importance of model responses to deviations from the long-run relationship.

With that in mind, Table 8 shows values for $\alpha$ from all three equations and the , $\gamma$ and $\phi$ values from the one co-integrating relationship of a VECM containing the real current account balance, Fed assets and the real interest rate. Full model results are in Appendix 2. The specifications are consistent with those of the Johansen tests, in that the post-2001 and post2007 dummies are exogenous, there are 5 lags, and the sample runs from 1982Q1-2013Q2. In the VECM we also incorporate three additional dummy variables to account for seasonality in the levels of either the real current account or real interest rate series. The negative estimate for the long-run coefficients ( $\gamma$ and $\phi$ ) indicate that there is an inverse relationship between the real interest rate and both $C A$ and $F A$ over the long-run. This is clear because the long-run relationship can be rewritten as $r=12.48-0.0463 C A-0.0102 F A$. So, if there is no change in US monetary settings, an unexpected current account deviation of \$1bn from the long-run relationship leads to a fall of 4.6 basis points (0.046\%) in the real interest rate over the longrun. Correspondingly, the addition of a US\$ billion to Fed assets depresses the long rate by a single basis point. The smallness of this effect is deceiving since the magnitude of Fed assets is ten-fold larger than the sum of China's and Japan's current account surpluses. ${ }^{24}$

The adjustment parameters show that the real interest rate, the real current account balance and the Fed assets measure all respond to deviations from the long-run relationship. For example, an unexpected difference in the long-run relationship of 1 unit, $r-\gamma C A-\phi F A-c=1$, leads to a fall of 10.3 basis points (-0.103\%) in terms of quarterly real interest rate differences. The logic behind this adjustment is that because the deviation from the long-run relationship is positive, the level of the real interest rate needs to decrease. Such a deviation causes different adjustments in the current account and Fed assets variables with the weight of adjustment assigned to Fed assets, allowing a positive change in the current account variable, which is opposite in direction from the change in the interest rate variable.

Taken together, the results from the various tests and the VECM provide support for the existence of a long-run inverse relationship between the Japanese and Chinese current account surpluses and the global natural rate that survives the post-GFC declining trend in those surpluses.

\footnotetext{
${ }^{24}$ The existence of this inverse relationship is also supported by co-integrating regressions, estimated using FMOLS or DOLS, which are available from the authors upon request.
} 


\section{Implications for Post-Transition Effects on Global Financial Markets}

Given the likelihood that the Chinese and Japanese current account surpluses will trend downward in future, it is of interest to simulate forward to examine the potential implications of this for the global natural rate. For this purpose we take the interest rate equation (2), individually, and combine it with exogenous projections for the current accounts and Fed assets to produce forecasts through 2025. The exogenous projections are illustrated in Figure 9. That for Fed assets is chosen simply because it offers comparative stability. Given the extraordinary in-sample behaviour of this variable and the absence of some of its determinants from the three equation system we do not expect the model to be a useful tool for the analysis of US monetary policy. Our focus is on the long interest rate and its dependence on Asian current accounts. To address that link we construct two future scenarios. First, we imagine that the sum of the Chinese and Japanese current accounts stabilises at around 2009 US\$ 60 billion. Alternatively, it continues to decline, stabilising later at a deficit of 2009 US\$ 10 billion.

The simulation results are shown in Figure 10. Since both scenarios see the collective current account surplus has trending lower than its values since 2003, there is some initial tightening. Steady states are reached, however, which show considerably higher rates in the current account deficit scenario than in the stabilising one. The difference turns out to be 3.3 percentage points, a result that had already been evident from the coefficient of the Chinese and Japanese current account surplus in the co-integrating relationship of the previous section. ${ }^{25}$ It is of interest to compare this result with the corresponding results from other studies. While their focus is not on the Asian savings glut, the studies by Warnock and Warnock (2006) estimate the links between external financial flows to the US and US bond yields. They look at East Asian surpluses through early 2005 and find they reduced the US 10 year bond yield to that point by something of the order of 100 basis points (Figure 4). Our result is larger but the East Asian surplus did not peak until 2007. Their results are, however, similar in magnitude to those from the more recent work of Beltran et al. (2011: medium run flow effects, Table 8), whose primary focus is on shorter lags and maturities. Approaches differ but the negative relationship between net financial inflows to the US and US long yields seems robust, supporting the view that the trend of excess saving in China and Japan is of potential significance in determining global long yields. A decline in their excess demand for long bonds could cause considerable tightening of global financial markets.

\footnotetext{
${ }^{25}$ In the co-integrating relationship a rise in the current account surplus of 1 US\$bn sees a fall in the real long yield of 46 basis points. Here the eventual difference in the current account scenarios is about 70 US\$bn.
} 


\section{Conclusion}

A substantial literature has developed on the effects of China's, and more generally Asian, growth on other regions and, more particularly, on the associated development of "upstream" financial flows. This paper offers evidence in support of the view that these Asian financial outflows have contributed to the declining trend in the global, natural rate of interest and that a reversal may be imminent that could cause a tightening trend. The question of the observability of the natural rate is addressed first. Evidence is presented that long bond markets are comparatively integrated across the advanced economies and that movements in the US long yield are useful proxies for corresponding movements in the underlying natural rate.

Bernanke’s much debated "savings glut” hypothesis is then broadened beyond the decade between the Asian and global financial crises and the focus is directed to the long term behaviour of Asian excess saving and the natural rate since 1980. Superficially, there is a clear inverse relationship between the trend of the Chinese and Japanese current account surpluses and that of long yields in the ensuing three decades. Moreover, the redirection of global economic growth toward Asia in that period, combined with Asian saving rates that have been consistently higher than the global average, suggests that Asia has contributed substantial shifts in ex ante saving sufficient to have caused the declining trend in rates.

The relationship between long yields and excess saving in China and Japan is then explored using a VECM that controls for US monetary policy. The results support a negative long term relationship between 10-year yields and the Chinese and Japanese current account surpluses. Projections using the same model then suggest that a feasible range of future pathways for those current accounts could cause the path of long rates to deviate by as much as 330 basis points over the next decade.

\section{References}

Beltran, D.O., M. Kretchmer, J. Marquez and C.P. Thomas (2012), "Foreign holdings of US Treasuries and US Treasury yields”, Federal Reserve System International Finance Discussion Paper No. 1041, Washington DC, January.

Bergsten, C.F., C. Freeman, N.R. Lardy and D.J. Mitchell (2008), China's Rise: Challenges and Opportunities, Washington DC: Peterson Institute for International Economics.

Bernanke, B. (2005a), "The global saving glut and the U.S. current account deficit”, The Homer Jones Lecture, St. Louis, Missouri (April 14). 
Bernanke, B.S. (2005b), “Remarks by the Governor”, Sandridge Lecture, Virginia Association of Economists, Richmond Virginia, March, Federal Reserve Board.

(2011), "Global imbalances: links to economic and financial stability”, speech given at the Banque de France Financial Stability Review Launch Event, Paris, France February 18.

Blanchard. O. and F. Giavazzi (2006), "Rebalancing growth in China: a three-handed approach," China and the World Economy, Institute of World Economics and Politics, Chinese Academy of Social Sciences, 14(4): 1-20.

Borio, C. and P. Disyatat (2011), "Global imbalances and the financial crisis: link or no link”, BIS Working Paper 346, Basel, May.

Burns, A., M. Kida, J. Lim, S. Mohapatra and M. Stocker (2014) "Unconventional monetary policy normalisation and emerging-market capital flows”, VOX: 21 January.

Caballero, R.J. (2009), “The 'other' imbalance and the financial crisis”, MIT Working Papers in Economics 9-32, Cambridge MA, December.

Caballero, R.J., E. Farhi and P.O. Gourinchas (2008), “An equilibrium model of 'global imbalances’ and low interest rates”, American Economic Review, 98(1): 358-393.

Cai, F. (2010), “Demographic transition, demographic dividend and Lewis turning point in China”, China Economic Journal, 3(2): 107-119, September.

Chinn, M.D., B. Eichengreen and H. Ito (2012), "Rebalancing global growth”, in O. Canuto and D. Leipziger (eds), Ascent after Descent: Regrowing Economic Growth after the Great Recession, Washington DC: World Bank: 35-86.

Chinn, M.D. and H. Ito (2007), “Current account balances, financial development and institutions: assaying the world 'saving glut'”, Journal of International Money and Finance, 26: 546-569.

Choi, H., N.C. Mark and D. Sul (2008), “Endogenous discounting, the world saving glut and the US current account”, Journal of International Economics, 75: 30-53.

Deer, L. and L. Song (2012), “China’s approach to rebalancing: a conceptual and policy framework”, China \& World Economy, 20(1): 1-26.

Dooley, M., D. Folkerts-Landau and P. M. Garber (2003), "An Essay on the Revived Bretton Woods System," NBER Working Paper no. 9971.

Dooley, M. and P. Garber (2005), "Is it 1958 or 1968? Three Notes on the Revived Bretton Woods System," Brookings Papers on Economic Activity 1, pp.147-187.

Dooley, M.P., P.M. Garber and D. Folkerts-Landau (2011), "Bretton Woods II still defines the international monetary system," NBER Working Paper 14731, February.

Eichengreen, B. (2004), "Global Imbalances and the Lessons of Bretton Woods," NBER, Working Paper 10497, Cambridge Mass: National Bureau of Economic Research.

Fukao, K. (2010), “Service sector productivity in Japan: the key to future economic growth”, Research Institute of Economy, Trade and Industry, IAA, Discussion Paper 10-P-007.

Fukao, M., (2010), "Financial crisis and long term stagnation in Japan: fiscal consolidation under deflationary pressures”, Keio-Kyoto Global Center of Excellence Discussion Paper DP2010-010.

Garnaut, R. (2010), “Macroeconomic implications of the turning point”, China Economic Journal, 3(2): 181-190, September. 
Garner, J. and H. Qiao (2013), “China - household consumption most likely US1.6 trillion larger than officially stated”, Asian Insight, Morgan Stanley Research, 28 February 2013, http://www.morganstanleychina.com/views/121217.html.

Golley, J. and Meng, X. (2011), “Has China run out of surplus labour?” Chinese Economic Review, 22(4): 555-572.

Goyal, R. and R. I. McKinnon (2003), “Japan’s Negative Risk Premium in Interest Rates: The Liquidity Trap and the Fall in Bank Lending”, The World Economy, 26 (March): 339363.

He, D. and P. Luk (2013), “A model of Chinese capital account liberalization”, Hong Kong Institute for Monetary Research Working Paper No.12/2013.

He, D. and R.N. McCauley (2013), “Transmitting global liquidity to East Asia: policy rates, bond yields, currencies and dollar credit”, Hong Kong Institute for Monetary Research Working Paper No.15/2013, BIS Working Papers 431, Bank for International Settlements, October.

He, D., L. Cheung, W. Zhang and T. Wu (2012), "How would capital account liberalization affect China's capital flows and renminbi real exchange rates?" China and the World Economy, 20(6): 29-54, November.

Henning, C.R. (2008), Accountability and Oversight of US Exchange Rate Policy, Washington DC: Peterson Institute for International Economics, June.

Horioka, C.Y. (2006), “The causes of Japan's 'lost decade': the role of household consumption”, Japan and the World Economy 18: 378-400.

Horioka, C.Y. and A. Terada-Hagiwara (2012), “The determinants and long term projections of saving rates in developing Asia”, Japan and the World Economy, 24: 128-137.

Horioka, C.Y. and J. Wan (2007), "The determinants of household saving in China: a dynamic panel analysis of provincial data.” Journal of Money, Credit and Banking 39(8): 2077-96.

Hoshi, T. and A.K.Kashyap, 2004. “Japan’s financial crisis and economic stagnation”, Journal of Economic Perspectives, 18(1): 3-26.

Huang, Y., J. Chang and L. Yang (2012), “Consumption recovery and economic rebalancing in China”, prepared for the Asian Economic Panel, March 22-23, Seoul, Korea, published in Asian Economic Papers, 12(1): 47-67, Winter/Spring 2013.

Ito, H. (2009), "US current account debate with Japan then, and China now”, Journal of Asian Economics, 20: 294-313.

(2013), "Monetary policy in Asia and the Pacific in the post, post-crisis era", presented at the 36th Pacific Trade and Development (PAFTAD) Conference, "Financial Development and Cooperation in Asia and the Pacific,” Hong Kong Monetary Authority, November 19-21, 2013.

Johnson, R.S., R.A. Zuber and J.M. Gandar (2010), “A re-examination of the market segmentation theory as a pedagogical model”, Journal of Financial Education, 36(1/2): 1-37, Spring/Summer.

Kehoe, T.J., K.J. Ruhl and J.B. Steinberg (2012), “A sudden stop to the savings glut and the future of the US economy”, Research Department Staff Report, Federal Reserve Bank of Minneapolis, August. 
King, M. and D. Low (2014), “Measuring the “world” interest rate”, NBER Working Paper No. 19887, Cambridge MA, February.

Kodres, L. and F.E. Warnock (2006), “The impact of petrodollars on US and emerging market bond yields”, Box 2.3, IMF, World Economic Outlook: Globalization and Inflation, April, Washington, D.C.:88-91.

Krugman, P. (2010) “Capital export, elasticity pessimism and the renminbi (wonkish)” New York Times (blog), 16 March.

Kuijs, L. (2006), “How will China’s saving-investment balance evolve?” World Bank Policy Research Working Paper 3958, Beijing, July.

Laibson, D. and J. Mollerstrom (2010), "Capital flows, consumption booms and asset bubbles: a behavioural alternative to the savings glut hypothesis", The Economic Journal, 120: 354-374, May.

Lardy, N.R. (2006), ‘Toward a consumption-driven growth path” Policy Brief 06-6, Washington DC: Peterson Institute for International Economics.

Lardy, N.R. (2012), Sustaining China's Growth after the Global Financial Crisis, Washington DC: Peterson Institute for International Economics, January.

Lee, J.W. and W.J. McKibbin (2007), "Domestic investment and external imbalances in East Asia”, CAMA Working Paper 4-2007, Canberra: Australian National University.

Lütkepohl, H. (2006). "Structural vector autoregressive analysis for cointegrated variables," AStA Advances in Statistical Analysis, Springer, 90(1):75-88, March.

Ma, G. and R.N. McCauley (2007), “How effective are China’s capital controls?”, Chapter 14 in R. Garnaut and L. Song (eds), China: Linking Markets for Growth, Asia-Pacific Press, July: 267-289.

Ma, G. and W. Yi (2010), “China’s high saving rate: myth and reality”, International Economics, 122: 5-40.

McKinnon, R.I. (2004), 'The East Asian Dollar Standard', China Economic Review, 15, 325330.

(2006), 'China's Exchange Rate Appreciation in the Light of the Earlier Japanese Experience', Pacific Economic Review, 11, 3, 287-98.

Modigliani, F. and S. Cao (2004), “The Chinese saving puzzle and the life-cycle hypothesis”, Journal of Economic Literature, 42(1), 145-170.

Rey, H. (2013), "Dilemma not trilemma: the global financial cycle and monetary policy independence”, Federal Reserve Bank of Kansas City Economic Symposium at Jackson Hole, August.

Riedel, J. (2011), “The slowing down of long term growth in Asia: natural causes, the middle income trap and politics”, School of Advanced International Studies, Johns Hopkins University.

Shiller, R. J., J.Y. Campbell and K.L. Schoenholtz (1983), "Forward rates and future policy: interpreting the term structure of interest rates", Brookings Papers on Economic Activity, 1983(1): 173-223.

Shin, H.S. (2011), “Global Banking Glut and Loan Risk Premium”, Presented at the 12th Jacques Polak Annual Research Conference Hosted by the International Monetary Fund, Washington, DC, November 10-11. 
Singh, A., M. Nabar and P.M. N'Daiye (2013), China's Economy in Transition: From External to Internal Rebalancing, International Monetary Fund, November.

Song, L., J. Yang and Y Zhang (2011), “State-owned enterprises' outward investment and the structural reform in China”, China and the World Economy, 19(4): 38-53.

Taylor, J.B. (2006), "Lessons from the recovery from the 'lost decade' in Japan: the case of the great intervention and monetary injection”, Background Paper for the International Conference of the Economics and Social Research Institute, Cabinet Office, Government of Japan, September.

Tyers, R. (2012), “Japan’s economic stagnation: causes and global implications”, The Economic Record, 88(283): 459-607, December.

(2013), “Looking inward for transformative growth in China”, CAMA Working Paper No. 48/2013, Centre for Applied Macroeconomics, Australian National University, Canberra, March.

(2014), “International effects of China’s rise and transition: neoclassical and Keynesian perspectives”, CAMA Working Paper No. 5-2014, Centre for Applied Macroeconomics, Australian National University, Canberra, July.

Tyers, R. and Y. Zhang (2011a), “Appreciating the renminbi”, The World Economy, 34(2): 265-297, February.

Tyers, R. and Y. Zhang (2011b), “Japan’s economic recovery: insights from multi-region dynamics”, CAMA Working Paper No. 18-2011, Australian National University, June

Warnock, F.E. and V.C. Warnock (2006), "International capital flows and US interest rates”, NBER Working Paper No. 12560, Cambridge, MA, October.

Wei, Shang-Jin and Xiaobo Zhang (2011) "The competitive saving motive: evidence from rising sex ratios and saving rates in China” Journal of Political Economy 199(3): 51164.

Wen Jiabao, (2011), Report on Work of the Government, www.npc.gov.cn, 5 March, accessed 24 March 2011.

Wen, Y. (2011), “Explaining China's trade imbalance puzzle”, Federal Reserve Bank of St Louis, Working Paper 2011-018A, St Louis, August.

Wicksell, K. (1898), Interest and prices: a study of the causes regulating the value of money, Translation from German, London: Macmillan, 1936.

Wood, A. (1994), North-South Trade, Employment and Inequality, Oxford: Clarendon Press.

World Bank (2013), Capital for the Future: Saving and Investment in an Interdependent World, Washington DC, 147 pp.

Yang, D.T. (2012), “Aggregate savings and external imbalances in China”, Journal of Economic Perspectives, 26, 4, 125-146.

Zhang, Y.S. and S. Barnett (2014), "Fiscal vulnerabilities and risks from local government finance in China”, IMF working Paper 14/4, Washington DC, January. 
Figure 1: Global Changes in the Real, Natural Rate of Interest

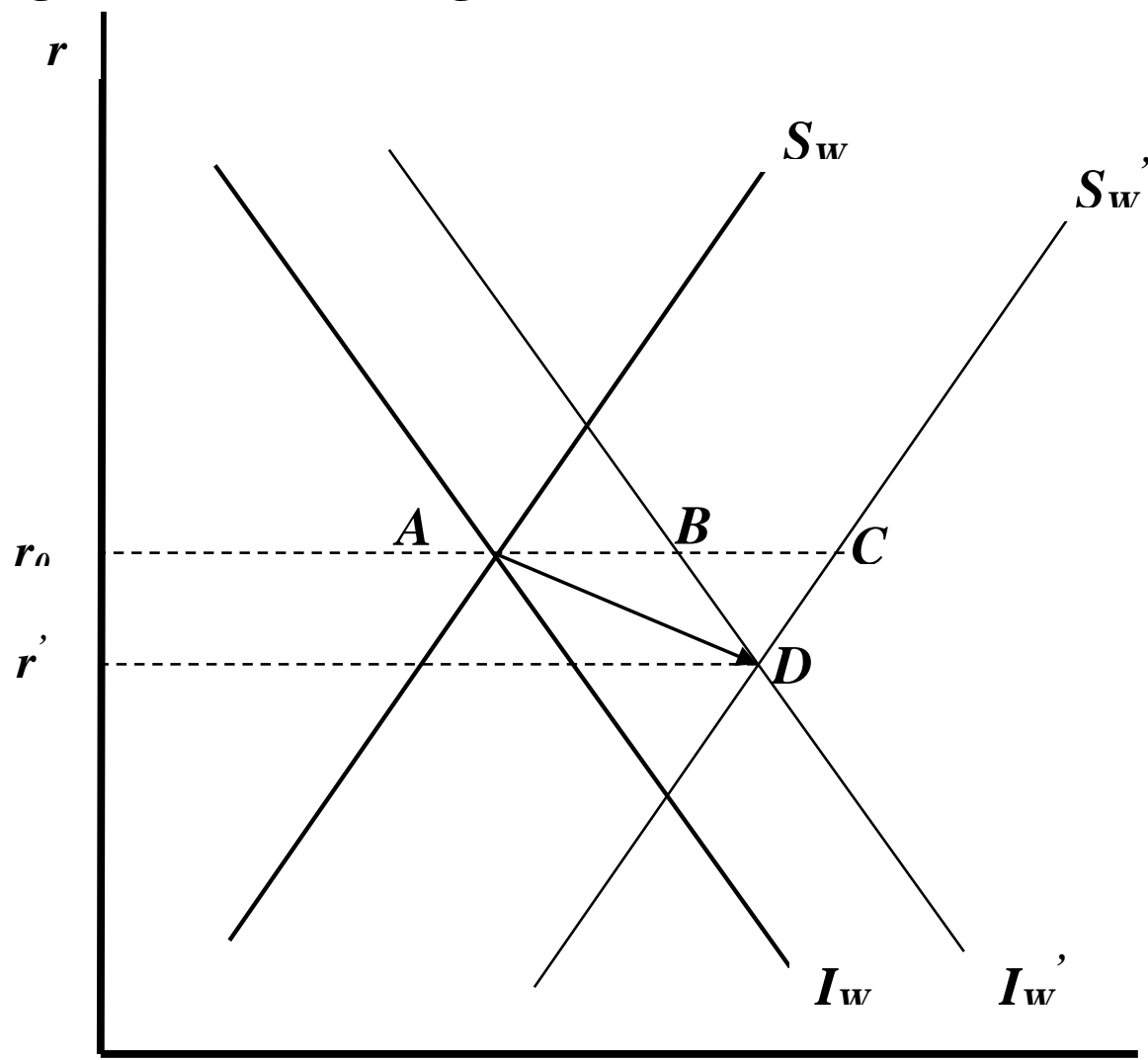

Figure 2: Global, Asian and Chinese Saving in US\$ (Log indices 1980=100)

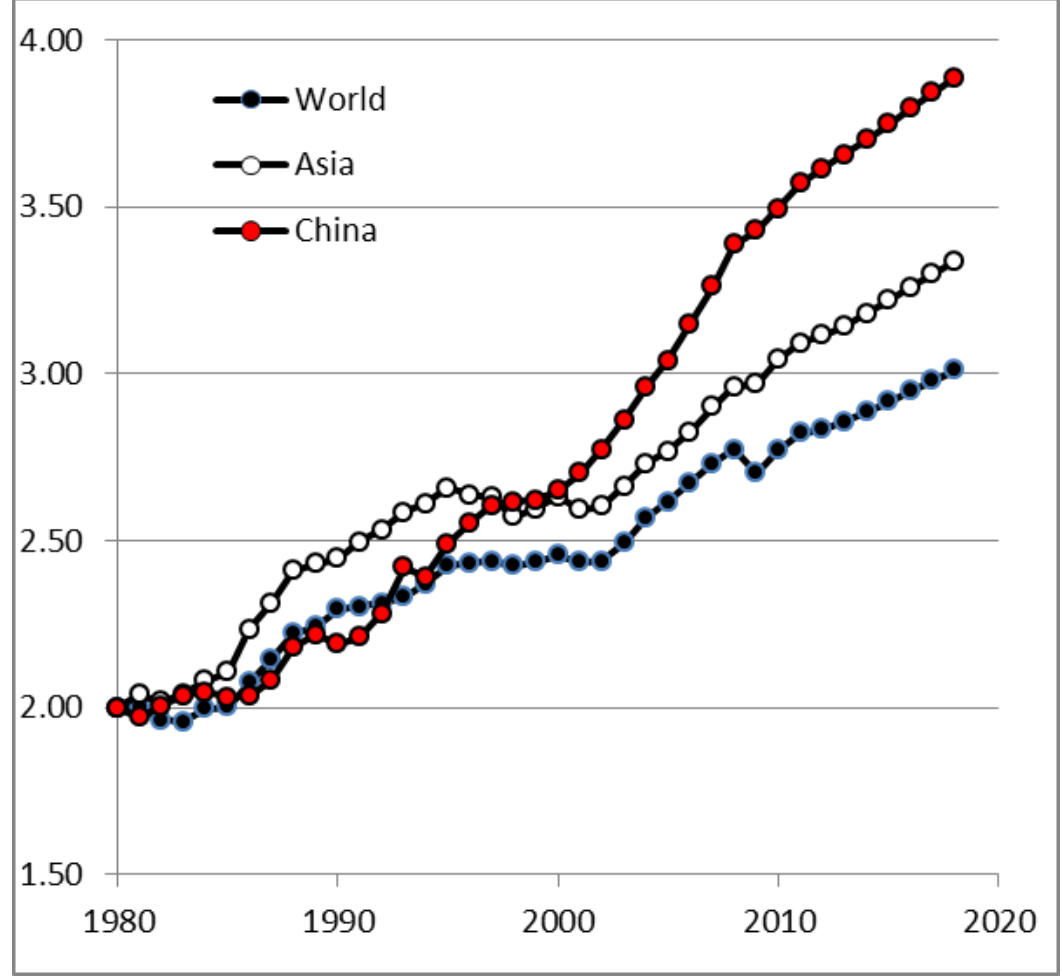

Source: IMF World Economic Outlook Database. 


\section{Figure 3: Long Term Bond Yields in Advanced Economies}

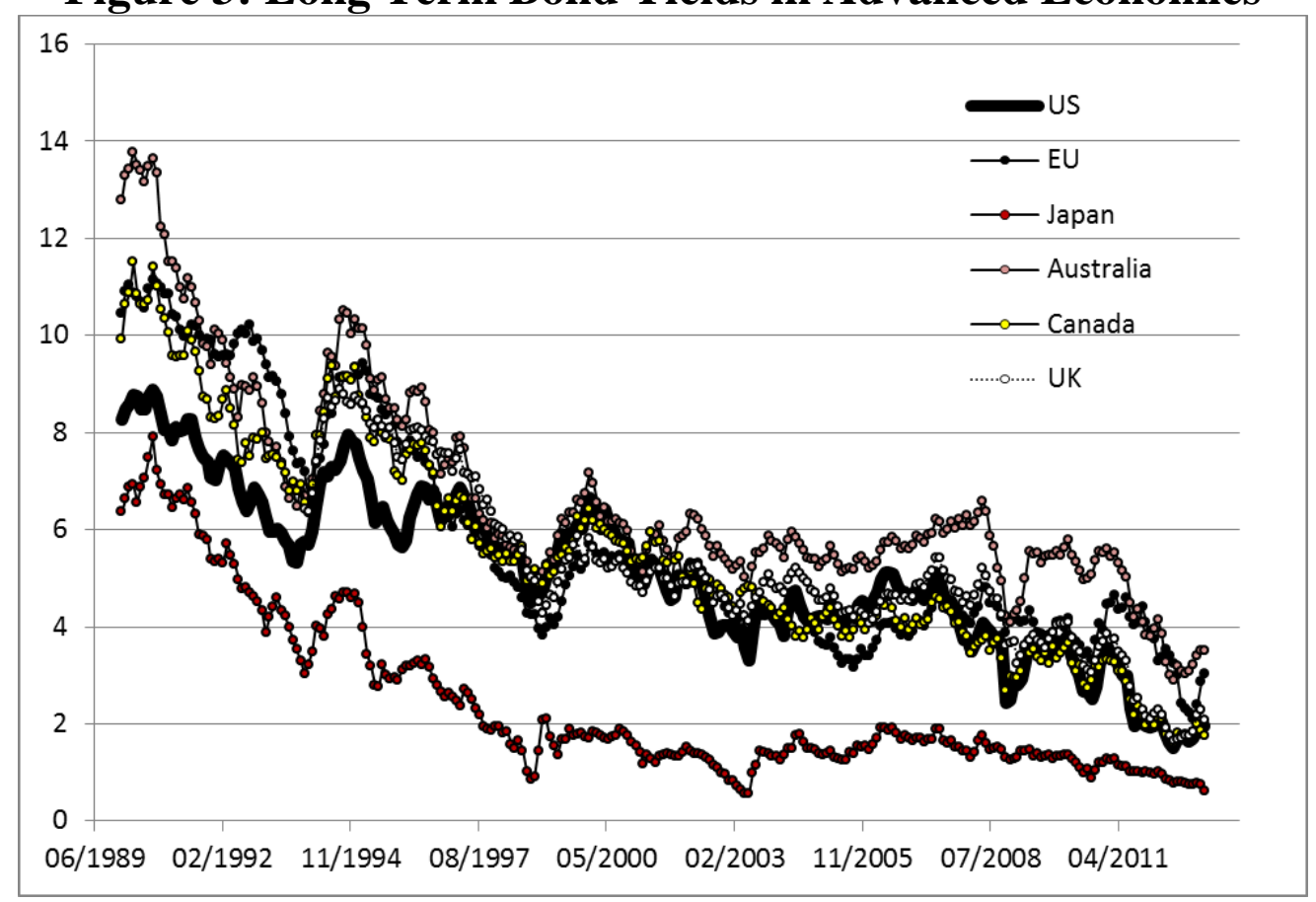

Sources: Bank of Canada, Bank of England, European Central Bank, Reserve Bank of Australia, US Federal Reserve Bank of St Louis (research.stlouisfed.org/fred2/series/).

Figure 4: Three Month Bond Yields in Advanced Economies

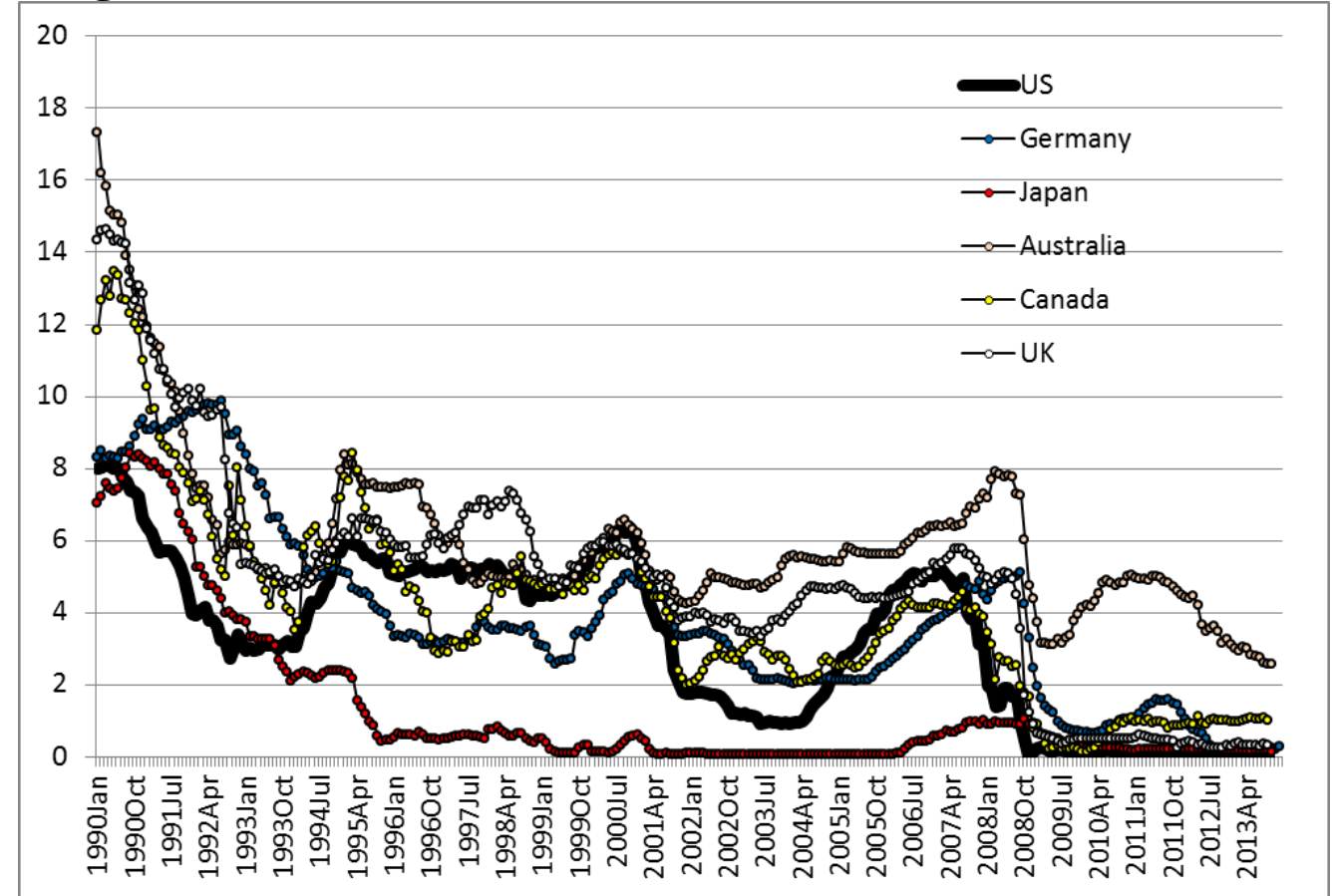

Sources: Federal Reserve Bank of St Louis (research.stlouisfed.org/fred2/series/), Bank of Canada and European Central Bank. 
Figure 5: Real US 10 Year Bond Yield vs China + Japan CA ${ }^{\mathrm{a}}$

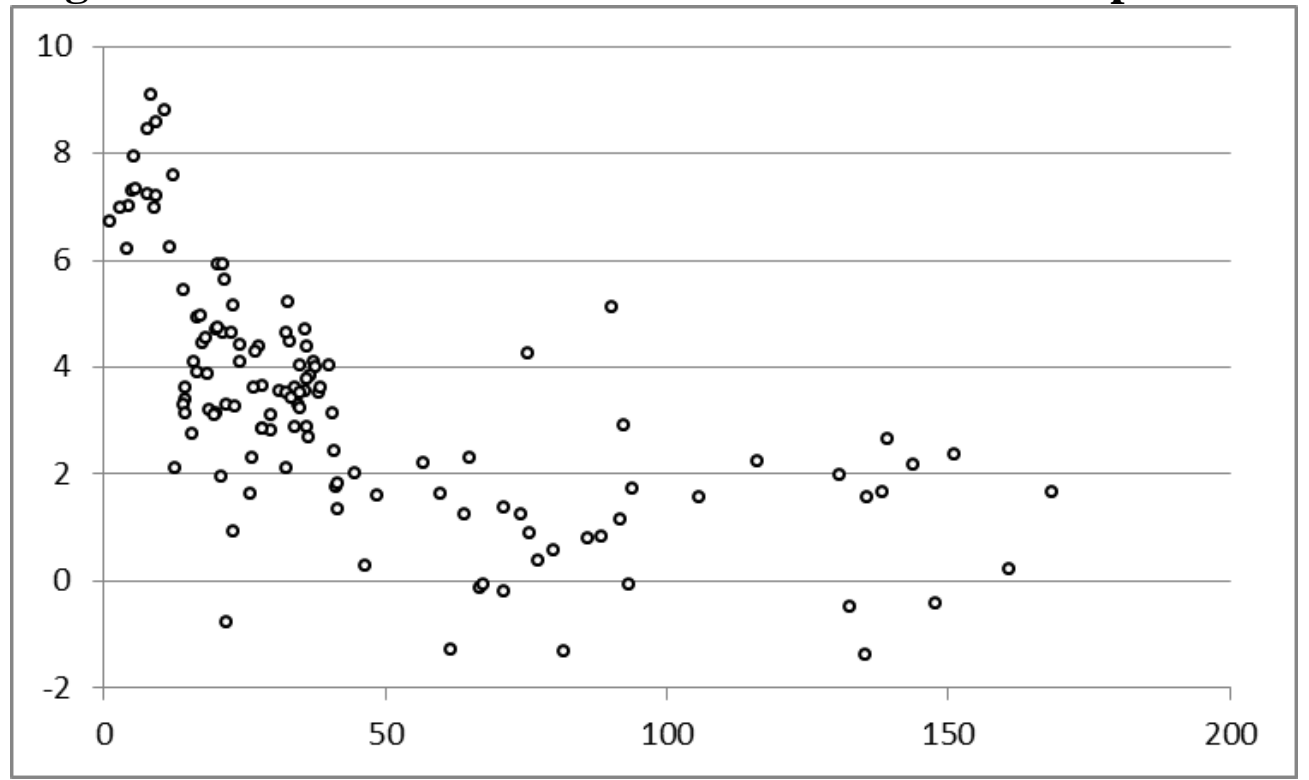

a The sum of Japan's and China's current account surpluses appears on the horizontal axis in US\$billions.

Sources: US Treasury rates from the Federal Reserve Board are deflated by previous-year CPI changes. The current accounts date back to 1980 and are quarterly from Oxford Economics in constant 2009US\$.

\section{Figure 6: China’s Governments’ Net Surpluses, US\$ Billions}

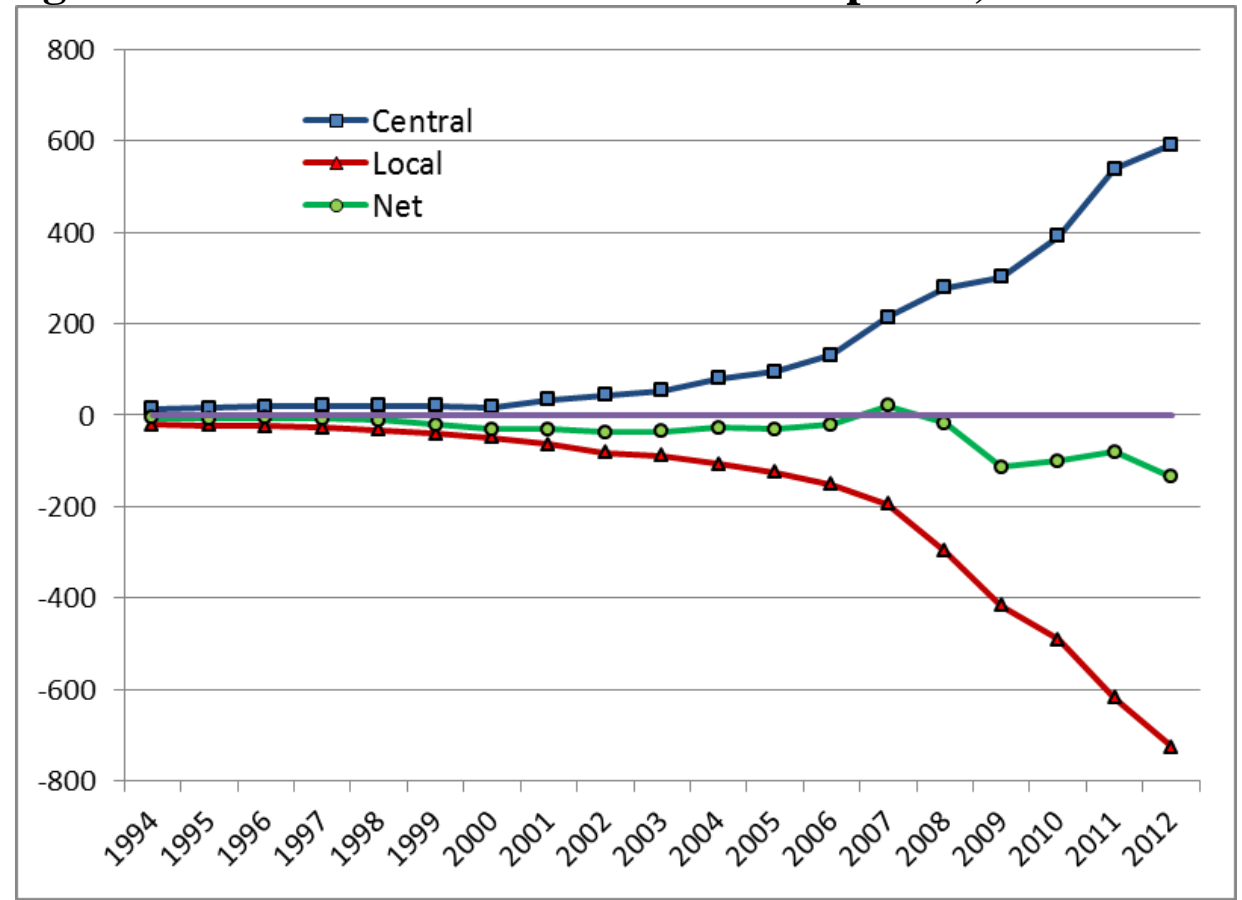

Sources: Government debt and general government gross debt position, IMF Fiscal monitor; External debt outstanding, Chinese statistical yearbook 2012. 
Figure 7: Standard Deviations of Regional Residuals from Log-Linear DeTrending

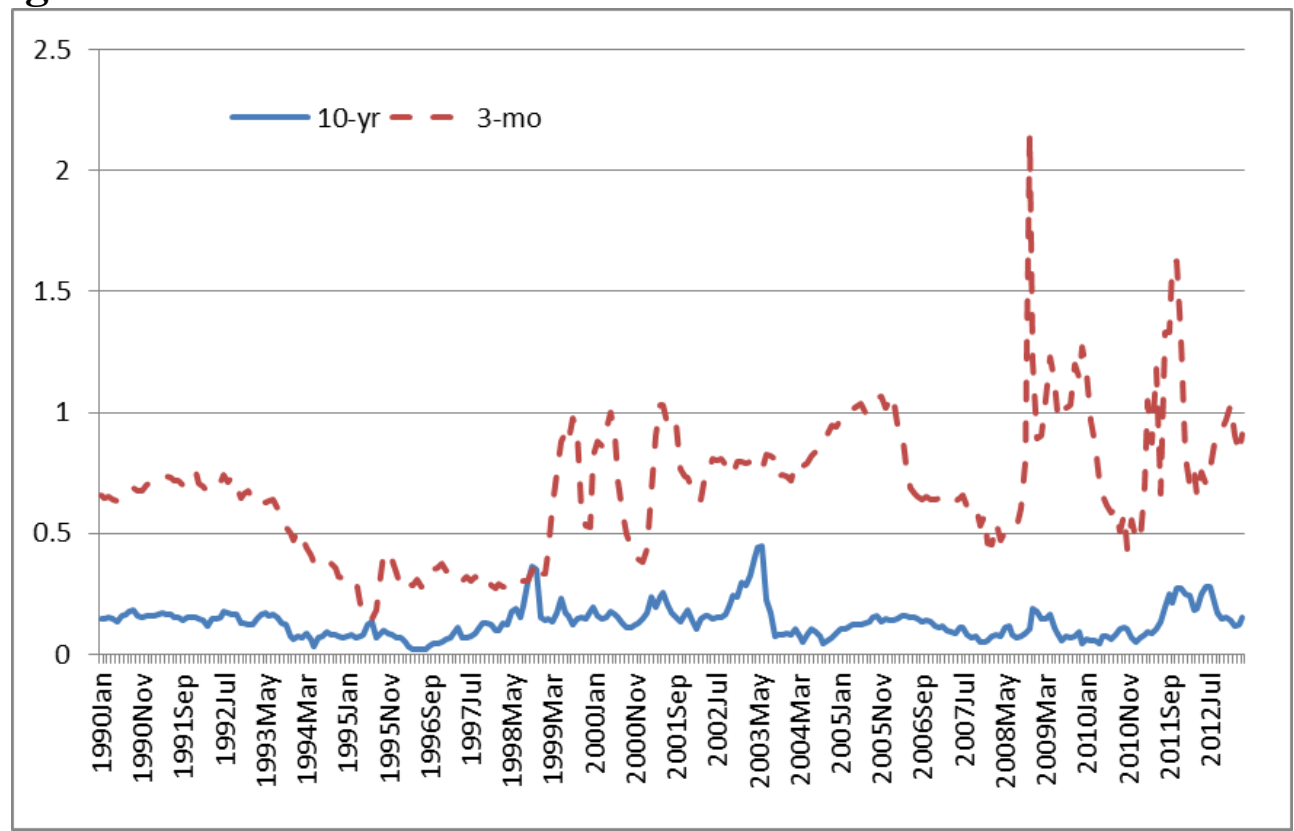

Sources: Calculations based on the yield series shown in Figures 3 and 4.

Figure 8: Variables in the VECM

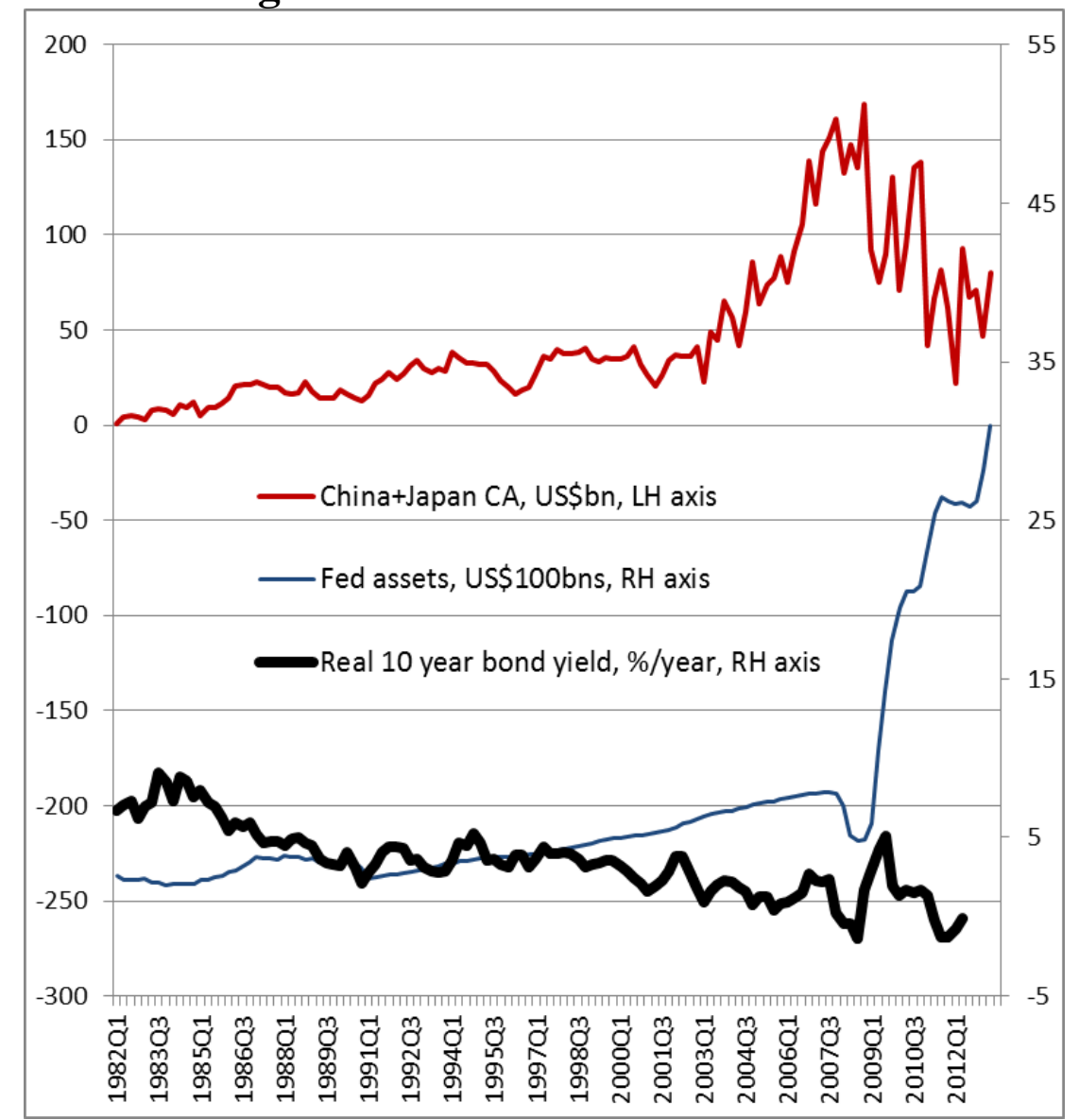

Sources: US Treasury rates from the Federal Reserve Board are deflated by previous-year CPI changes. The current accounts date back to 1980 and are quarterly from Oxford Economics in constant 2009US\$. The Fed assets series is detailed in Appendix 2. 
Figure 9: Exogenous Trends in Forecasts

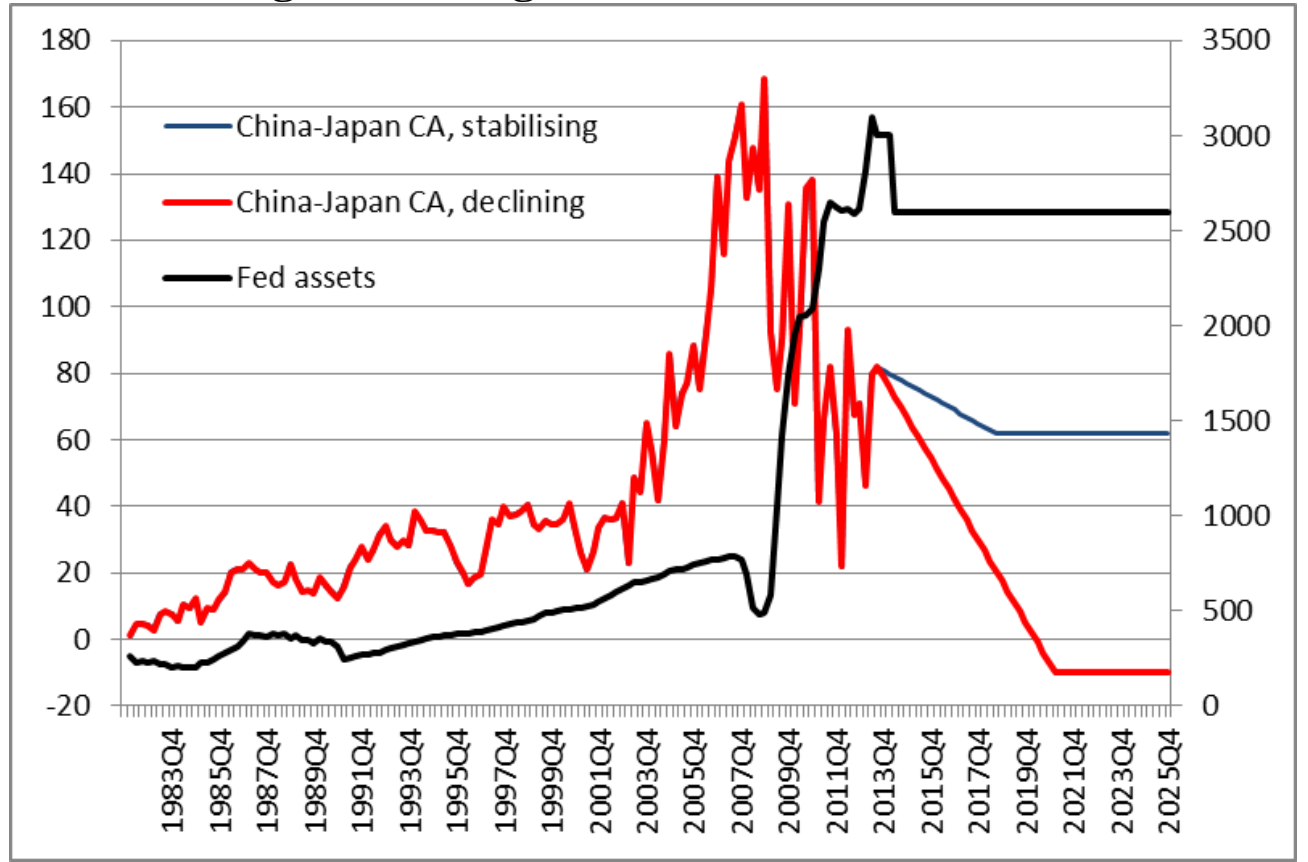

Sources: Raw data from Figure 9 and authors exogenous projections.

Figure 10: Forecast US 10 Year Bond Yield

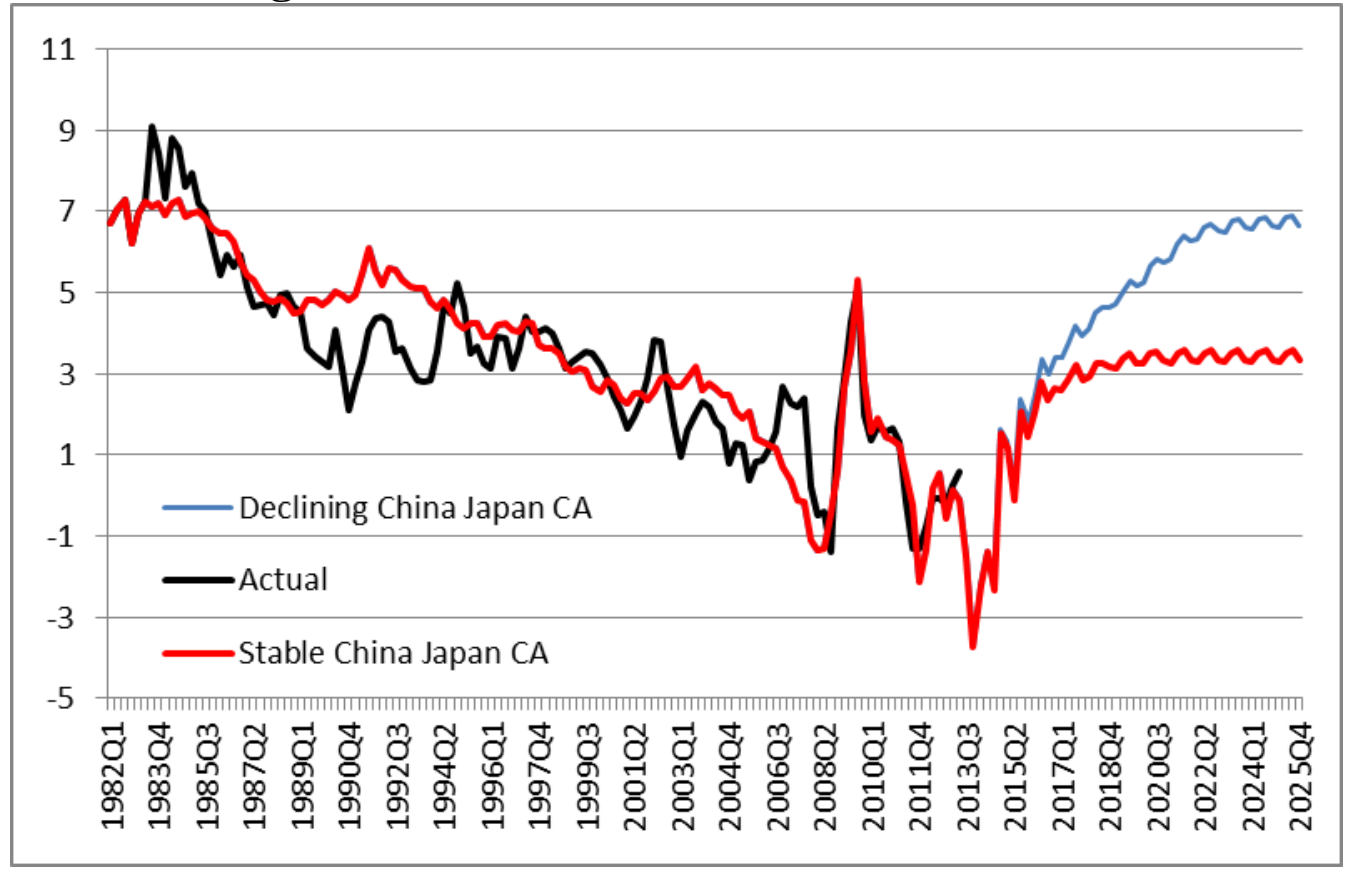

Source: Raw data on yields, in-sample fitted values from the real interest rate equation in the text and forecasts based on the exogenous trends indicated in Figure 10. 
Table 1: Increments to Global, Asian and Chinese GDP, Saving 1980-2012:

\begin{tabular}{lcccc}
\hline & \multicolumn{2}{c}{$1980-2012$} & \multicolumn{2}{c}{$1990-2012$} \\
\hline & GDP & Saving & GDP & Saving \\
\hline US\$ trillions & 61 & 15 & 50 & 12 \\
Share of Asia & 30 & 46 & 32 & 47 \\
Share of China & 13 & 27 & 16 & 32 \\
\hline
\end{tabular}

Source: IMF, World Economic Database.

Table 2: Relative Economic Sizes of China and Other Large Regions, 2011:

\begin{tabular}{lllll}
\hline \multicolumn{1}{c}{ \% of world } & China & US & EU(26) & Japan \\
\hline GDP & 11 & 22 & 26 & 9 \\
Consumption, $C$ & 8 & 27 & 26 & 9 \\
Investment, $I$ & 20 & 15 & 22 & 8 \\
Government spending, $G$ & 7 & 20 & 30 & 10 \\
Exports, $X$ & 17 & 17 & 25 & 7 \\
Imports, $M$ & 15 & 21 & 23 & 8 \\
Total domestic saving, $S^{D}$ & 19 & 13 & 20 & 9
\end{tabular}

Sources: National accounts data supply most of the elements though adjustments have been required to ensure that current accounts sum to zero globally, as do capital/financial accounts. The IMF-IFS database is the major source but there is frequent resort to national statistical databases.

Table 3: Unit Root Tests for Nominal Interest Rate Levels in $\%^{\mathrm{a}}$

\begin{tabular}{lcccccc}
\hline \multicolumn{1}{c}{ series } & ADF & PP & KPSS & ADF & PP & KPSS \\
\hline $\log ($ US $)$ & -2.976 & -2.982 & $0.393^{* * *}$ & -1.300 & -1.903 & $0.800^{* * *}$ \\
$\log ($ EU) & -2.942 & -2.679 & $0.688^{* * *}$ & -2.899 & -1.122 & $0.409^{* * *}$ \\
$\log ($ Japan $)$ & -2.165 & -2.572 & $0.909^{* * *}$ & -1.796 & -1.660 & $1.040^{* * *}$ \\
$\log$ (Australia) & $-3.377^{*}$ & -2.886 & $0.420^{* * *}$ & $-3.496^{* *}$ & -2.899 & $0.313^{* * *}$ \\
$\log ($ Canada) & -2.878 & -2.830 & $0.252^{* * *}$ & -3.222 & -2.489 & $0.241^{* * *}$ \\
$\log (\mathrm{UK})$ & -3.128 & -2.924 & $0.313^{* * *}$ & -1.806 & -1.356 & $0.817^{* * *}$ \\
\hline
\end{tabular}

a.Augmented Dickey-Fuller(ADF) test: reported are the $\mathrm{Z}(\mathrm{t})$ test statistics. Four lags are used in the test.

Critical values are: $1 \%=-3.989,5 \%=-3.429,10 \%=-3.13$.

Phillips-Perron(PP) test: Four lags are used in the test. Critical values are $1 \%=-1.796,5 \%=-3.429$, $10 \%=3.13$.

Kwiatkowski, Phillips, Schmidt, and Shin(KPSS) test: four lags are used. The null hypothesis is trend stationarity. Critical values are $1 \%=0.216,5 \%=0.146,10 \%=0.119$.

$* *(* * *)$ indicates significance at the 5(1) percent level. 
Table 4: Co-integration Tests for 10-Year Interest Rates ${ }^{\mathrm{a}}$

\begin{tabular}{ccccc}
\hline Maximum rank & Trace statistic & Max statistic & SBIC & HQIC \\
\hline 0 & 142.283 & 53.050 & $-21.080^{*}$ & -21.409 \\
& $(114.9)$ & $(43.97)$ & & \\
1 & 89.233 & $36.173^{*}$ & -21.028 & -21.451 \\
& $(87.31)$ & $(37.52)$ & & \\
2 & $53.059^{*}$ & 21.801 & -20.956 & $-21.457^{*}$ \\
& $(62.99)$ & $(31.46)$ & & -21.436 \\
& 31.258 & 15.382 & -20.872 & -21.417 \\
4 & $(42.44)$ & $(25.54)$ & & \\
& 15.876 & 9.071 & -20.806 & -21.400 \\
5 & $(25.32)$ & $(18.96)$ & & \\
6 & 6.805 & 6.805 & -20.757 & -21.399 \\
\hline
\end{tabular}

a The $5 \%$ critical value is in parentheses.

Table 5: Co-integration Tests for 3-Month Interest Rates

\begin{tabular}{ccccc}
\hline Maximum rank & Trace statistic & Max statistic & SBIC & HQIC \\
\hline 0 & $100.371^{*}$ & $39.611^{*}$ & $-11.006^{*}$ & $-11.330^{*}$ \\
& $(114.9)$ & $(43.97)$ & & \\
1 & 60.758 & 23.639 & -10.907 & -11.324 \\
& $(87.31)$ & $(37.52)$ & & \\
2 & 37.119 & 15.739 & -10.791 & -11.285 \\
& $(62.99)$ & $(31.46)$ & & \\
3 & 21.379 & 11.573 & -10.687 & -11.242 \\
4 & $(42.44)$ & $(25.54)$ & & -11.210 \\
& 9.806 & 5.434 & -10.608 & \\
5 & $(25.32)$ & $(18.96)$ & & -11.181 \\
& 4.372 & 4.372 & -10.547 & -11.171 \\
\hline
\end{tabular}

a The $5 \%$ critical value is in parentheses.

Table 6: Correlations between Trend-Deviations of US and Other Economies' Interest Rates ${ }^{\mathrm{a}}$

\begin{tabular}{lllllll}
\hline \multicolumn{3}{c}{10 year } & \multicolumn{3}{c}{3 month } \\
\hline & $1990-$ & $1998-$ & $2008-$ & $1990-$ & $1998-$ & $2008-$ \\
& 1997 & 2007 & 2013 & 1997 & 2007 & 2013 \\
\hline EU & 0.094 & 0.655 & 0.487 & -0.879 & 0.746 & 0.346 \\
Japan & 0.132 & 0.834 & 0.829 & -0.796 & 0.711 & 0.557 \\
Australia & 0.606 & 0.800 & 0.933 & 0.080 & 0.777 & 0.460 \\
Canada & 0.725 & 0.719 & 0.968 & 0.074 & 0.889 & 0.337 \\
UK & 0.768 & 0.716 & 0.921 & 0.619 & 0.804 & 0.718 \\
\hline \\
a All interest rate series are log-linear de-trended. Correlation coefficients between pairs of rates are \\
presented.
\end{tabular}


Table 7: Summary Statistics for Annual Differences ${ }^{\mathrm{a}}$

\begin{tabular}{|c|c|c|c|c|}
\hline & Mean & $\begin{array}{l}\text { Standard } \\
\text { Deviation }\end{array}$ & Skewness & Kurtosis \\
\hline Real East Asian CA Balance $(\Delta \$ B n)$ & 3.42 & 64.21 & -0.045 & 5.05 \\
\hline Real Interest Rate $(\Delta \%)$ & -0.068 & 1.92 & 1.22 & 5.62 \\
\hline Fed Assets $(\Delta \$ B n)$ & 108.47 & 269.66 & 2.81 & 11.66 \\
\hline
\end{tabular}

Table 8: VECM Results for Long-Run Coefficients

\begin{tabular}{lccc}
\hline Equation & $\gamma$ & $\phi$ & $\alpha$ \\
\hline Real Interest Rate & & & $-0.103^{* * *}$ \\
Real Current Account & $0.0463^{* * *}$ & $0.0102^{* * *}$ & $1.497^{* * *}$ \\
Fed Assets & & $-6.616^{* * *}$ \\
\hline Sources: For full estimation results, see Appendix 2. & &
\end{tabular}


Appendix 1: Market Integration Analysis

Table A.1: Lag-Order Selection Test Statistics

\begin{tabular}{ccccccc}
\hline & \multicolumn{3}{c}{ 10 year } & \multicolumn{3}{c}{ 3 month } \\
lag & AIC & HQIC & SBIC & AIC & HQIC & SBIC \\
\hline 0 & -6.43 & -6.39 & -6.35 & 9.04 & 9.07 & 9.12 \\
1 & -20.72 & -20.50 & -20.16 & -10.22 & -10.00 & -9.67 \\
2 & $21.75^{*}$ & $-21.33^{*}$ & $-20.71^{*}$ & -11.48 & $-11.08^{*}$ & $-10.46^{*}$ \\
3 & -21.69 & -21.09 & -20.18 & -11.46 & -10.86 & -9.97 \\
4 & -21.63 & -20.83 & -19.64 & -11.49 & -10.70 & -9.53 \\
5 & -21.58 & -20.58 & -19.10 & -11.39 & -10.42 & -8.96 \\
6 & -21.54 & -20.36 & -18.59 & -11.42 & -10.26 & -8.52 \\
7 & -21.51 & -20.13 & -18.08 & -11.60 & -10.25 & -8.22 \\
8 & -21.36 & -19.79 & -17.45 & $-11.74^{*}$ & -10.193 & -7.89 \\
\hline
\end{tabular}

Table A.2: Correlation Matrix, 10-year Interest Rates of US and Other Economies ${ }^{\mathrm{a}}$

\begin{tabular}{|c|c|c|c|c|c|c|}
\hline & \multicolumn{6}{|c|}{ 1990-1997 } \\
\hline US & 1 & & & & & \\
\hline EU & 0.094 & 1 & & & & \\
\hline Japan & 0.132 & 0.688 & 1 & & & \\
\hline Australia & 0.606 & 0.680 & 0.682 & 1 & & \\
\hline Canada & 0.725 & 0.532 & 0.427 & 0.834 & 1 & \\
\hline \multirow[t]{2}{*}{ UK } & 0.768 & 0.404 & 0.407 & 0.852 & 0.773 & 1 \\
\hline & \multicolumn{6}{|c|}{ 1998-2007 } \\
\hline US & 1 & & & & & \\
\hline $\mathbf{E U}$ & 0.655 & 1 & & & & \\
\hline Japan & 0.834 & 0.504 & 1 & & & \\
\hline Australia & 0.800 & 0.780 & 0.788 & 1 & & \\
\hline Canada & 0.719 & 0.763 & 0.543 & 0.781 & 1 & \\
\hline \multirow[t]{2}{*}{ UK } & 0.716 & 0.698 & 0.795 & 0.914 & 0.680 & 1 \\
\hline & \multicolumn{6}{|c|}{ 2008-2013 } \\
\hline US & 1 & & & & & \\
\hline $\mathbf{E U}$ & 0.487 & 1 & & & & \\
\hline Japan & 0.829 & 0.646 & 1 & & & \\
\hline Australia & 0.933 & 0.550 & 0.760 & 1 & & \\
\hline Canada & 0.968 & 0.490 & 0.810 & 0.934 & 1 & \\
\hline UK & 0.921 & 0.399 & 0.784 & 0.896 & 0.934 & 1 \\
\hline
\end{tabular}


Table A.3 Correlation Matrix : 3-Month Interest Rates of US and Other Economies US EU Japan Australia Canada UK 1990-1997

\begin{tabular}{|c|c|c|c|c|c|c|}
\hline US & 1 & & & & & \\
\hline EU & -0.879 & 1 & & & & \\
\hline Japan & -0.796 & 0.839 & 1 & & & \\
\hline Australia & 0.080 & -0.029 & 0.322 & 1 & & \\
\hline Canada & 0.074 & 0.037 & 0.309 & 0.738 & 1 & \\
\hline \multirow[t]{2}{*}{ UK } & 0.619 & -0.352 & -0.268 & 0.525 & 0.279 & 1 \\
\hline & \multicolumn{6}{|c|}{ 1998-2007 } \\
\hline US & 1 & & & & & \\
\hline $\mathbf{E U}$ & 0.746 & 1 & & & & \\
\hline Japan & 0.711 & 0.724 & 1 & & & \\
\hline Australia & 0.777 & 0.769 & 0.592 & 1 & & \\
\hline Canada & 0.889 & 0.787 & 0.759 & 0.813 & 1 & \\
\hline \multirow[t]{2}{*}{ UK } & 0.804 & 0.751 & 0.632 & 0.936 & 0.774 & 1 \\
\hline & \multicolumn{6}{|c|}{ 2008-2013 } \\
\hline US & 1 & & & & & \\
\hline EU & 0.346 & 1 & & & & \\
\hline Japan & 0.557 & 0.643 & 1 & & & \\
\hline Australia & 0.460 & 0.769 & 0.320 & 1 & & \\
\hline Canada & 0.337 & 0.341 & 0.192 & 0.597 & 1 & \\
\hline UK & 0.718 & 0.780 & 0.729 & 0.811 & 0.518 & 1 \\
\hline
\end{tabular}




\section{Appendix 2: Vector Error Correction Analysis}

\section{Data Details}

The raw data are available at various frequencies through 2013Q2, and are not seasonally adjusted (instead, seasonal dummies are used in the estimating model). The 10 year real U.S. interest rates are computed by subtracting observed CPI inflation, taken from the U.S. Bureau of Labor Statistics (BLS), over the previous year from the nominal 10 year U.S. Treasury rate, taken from the Federal Reserve. The nominal rates are daily, averaged to monthly. Real rates are calculated at this monthly frequency, and then averaged to quarterly for use in the analysis. The real Chinese and Japanese current account balances are summed as nominal US\$ values. They are drawn Oxford Economics at a quarterly frequency in billions of USD beginning in 1980, and are deflated to \$2009 using the US CPI from the BLS (which is averaged to quarterly for the calculation). The Fed assets are securities held outright by the Federal Reserve. They are available from 1989Q1 in billions of dollars, and are taken from the Federal Reserve. The series is back-cast for earlier periods based on quarterly movements in the US monetary base.

\section{VECM Estimation}

\begin{tabular}{|c|c|c|c|}
\hline \multicolumn{4}{|c|}{ Eviews results } \\
\hline \multicolumn{4}{|c|}{ Sample: 1982Q1 2013Q2 } \\
\hline \multicolumn{4}{|c|}{ Included observations: 119} \\
\hline \multicolumn{4}{|c|}{ Standard errors in ( ) \& t-statistics in [ ] } \\
\hline \multicolumn{4}{|l|}{$\begin{array}{l}\text { Co-integrating } \\
\text { Equation }\end{array}$} \\
\hline & & & \\
\hline RINT10(-1) & 1.000000 & & \\
\hline \multirow[t]{3}{*}{ CHJP_CA(-1) } & 0.046282 & & \\
\hline & $(0.01507)$ & & \\
\hline & {$[3.07130]$} & & \\
\hline \multirow[t]{3}{*}{ FED_ASSETS(-1) } & 0.010244 & & \\
\hline & $(0.00131)$ & & \\
\hline & [ 7.79452] & & \\
\hline C & -12.48179 & & \\
\hline Error Correction: & $\mathrm{D}(\mathrm{RINT10})$ & $\mathrm{D}(\mathrm{CHJP} \mathrm{CA}$ & (FED_ASSETS) \\
\hline \multirow[t]{3}{*}{ CointEq1 } & -0.102694 & 1.497461 & \\
\hline & $(0.03058)$ & $(0.47730)$ & $(1.60907)$ \\
\hline & {$[-3.35802]$} & [ 3.13734] & {$[-4.11197]$} \\
\hline
\end{tabular}




\begin{tabular}{|c|c|c|c|}
\hline D(RINT10(-1)) & $\begin{array}{l}0.023150 \\
(0.09810) \\
{[0.23598]}\end{array}$ & $\begin{array}{l}1.316875 \\
(1.53113) \\
{[0.86007]}\end{array}$ & $\begin{array}{l}3.241581 \\
(5.16170) \\
{[0.62801]}\end{array}$ \\
\hline D(RINT10(-2)) & $\begin{array}{c}-0.057368 \\
(0.09146) \\
{[-0.62725]}\end{array}$ & $\begin{array}{l}1.632886 \\
(1.42747) \\
{[1.14390]}\end{array}$ & $\begin{array}{l}19.19558 \\
(4.81225) \\
{[3.98890]}\end{array}$ \\
\hline D(RINT10(-3)) & $\begin{array}{l}0.113008 \\
(0.09416) \\
{[1.20018]}\end{array}$ & $\begin{array}{c}0.103466 \\
(1.46958) \\
{[0.07041]}\end{array}$ & $\begin{array}{c}-9.283899 \\
(4.95421) \\
{[-1.87394]}\end{array}$ \\
\hline $\mathrm{D}(\mathrm{RINT10}(-4))$ & $\begin{array}{c}-0.148202 \\
(0.09497) \\
{[-1.56045]}\end{array}$ & $\begin{array}{c}-0.295017 \\
(1.48231) \\
{[-0.19903]}\end{array}$ & $\begin{array}{l}6.763354 \\
(4.99712) \\
{[1.35345]}\end{array}$ \\
\hline D(RINT10(-5)) & $\begin{array}{l}0.173223 \\
(0.09107) \\
{[1.90210]}\end{array}$ & $\begin{array}{c}2.426424 \\
(1.42137) \\
{[1.70710]}\end{array}$ & $\begin{array}{c}-7.998437 \\
(4.79168) \\
{[-1.66923]}\end{array}$ \\
\hline $\mathrm{D}\left(\mathrm{CHJP} \_\mathrm{CA}(-1)\right)$ & $\begin{array}{l}0.006606 \\
(0.00621) \\
{[1.06466]}\end{array}$ & $\begin{array}{r}-0.475316 \\
(0.09685) \\
{[-4.90789]}\end{array}$ & $\begin{array}{r}0.045581 \\
(0.32649) \\
{[0.13961]}\end{array}$ \\
\hline $\mathrm{D}\left(\mathrm{CHJP} \_\mathrm{CA}(-2)\right)$ & $\begin{array}{l}0.000480 \\
(0.00641) \\
{[0.07490]}\end{array}$ & $\begin{array}{c}-0.569888 \\
(0.10006) \\
{[-5.69542]}\end{array}$ & $\begin{array}{l}1.319864 \\
(0.33732) \\
{[3.91278]}\end{array}$ \\
\hline D(CHJP_CA(-3)) & $\begin{array}{c}-0.009480 \\
(0.00693) \\
{[-1.36746]}\end{array}$ & $\begin{array}{c}-0.467760 \\
(0.10820) \\
{[-4.32323]}\end{array}$ & $\begin{array}{l}1.145533 \\
(0.36475) \\
{[3.14060]}\end{array}$ \\
\hline D(CHJP_CA(-4)) & $\begin{array}{c}-0.005087 \\
(0.00710) \\
{[-0.71676]}\end{array}$ & $\begin{array}{c}0.083426 \\
(0.11076) \\
{[0.75319]}\end{array}$ & $\begin{array}{l}1.143998 \\
(0.37340) \\
{[3.06372]}\end{array}$ \\
\hline D(CHJP_CA(-5)) & $\begin{array}{c}-0.001696 \\
(0.00677) \\
{[-0.25071]}\end{array}$ & $\begin{array}{c}-0.439132 \\
(0.10560) \\
{[-4.15865]}\end{array}$ & $\begin{array}{l}0.431124 \\
(0.35598) \\
{[1.21110]}\end{array}$ \\
\hline D(FED_ASSETS(-1)) & $\begin{array}{c}-0.000129 \\
(0.00186) \\
{[-0.06962]}\end{array}$ & $\begin{array}{l}0.017282 \\
(0.02902) \\
{[0.59556]}\end{array}$ & $\begin{array}{l}0.684890 \\
(0.09783) \\
{[7.00115]}\end{array}$ \\
\hline D(FED_ASSETS(-2)) & $\begin{array}{l}-0.007890 \\
(0.00232) \\
{[-3.40695]}\end{array}$ & $\begin{array}{l}0.004871 \\
(0.03614) \\
{[0.13477]}\end{array}$ & $\begin{array}{c}-0.233685 \\
(0.12185) \\
{[-1.91787]}\end{array}$ \\
\hline D(FED_ASSETS(-3)) & $\begin{array}{c}0.001172 \\
(0.00240) \\
{[0.48794]}\end{array}$ & $\begin{array}{c}-0.019864 \\
(0.03748) \\
{[-0.52994]}\end{array}$ & $\begin{array}{l}0.125015 \\
(0.12636) \\
{[0.98933]}\end{array}$ \\
\hline D(FED_ASSETS(-4)) & $\begin{array}{l}0.003705 \\
(0.00221) \\
{[1.67439]}\end{array}$ & $\begin{array}{c}0.059802 \\
(0.03454) \\
{[1.73141]}\end{array}$ & $\begin{array}{c}-0.114802 \\
(0.11644) \\
{[-0.98594]}\end{array}$ \\
\hline D(FED_ASSETS(-5)) & $\begin{array}{c}-0.003216 \\
(0.00184) \\
{[-1.74301]}\end{array}$ & $\begin{array}{l}0.010155 \\
(0.02880) \\
{[0.35264]}\end{array}$ & $\begin{array}{l}-0.154677 \\
(0.09707) \\
{[-1.59337]}\end{array}$ \\
\hline C & $\begin{array}{c}-0.578441 \\
(0.17237)\end{array}$ & $\begin{array}{l}9.393396 \\
(2.69021)\end{array}$ & $\begin{array}{c}-25.43064 \\
(9.06914)\end{array}$ \\
\hline
\end{tabular}




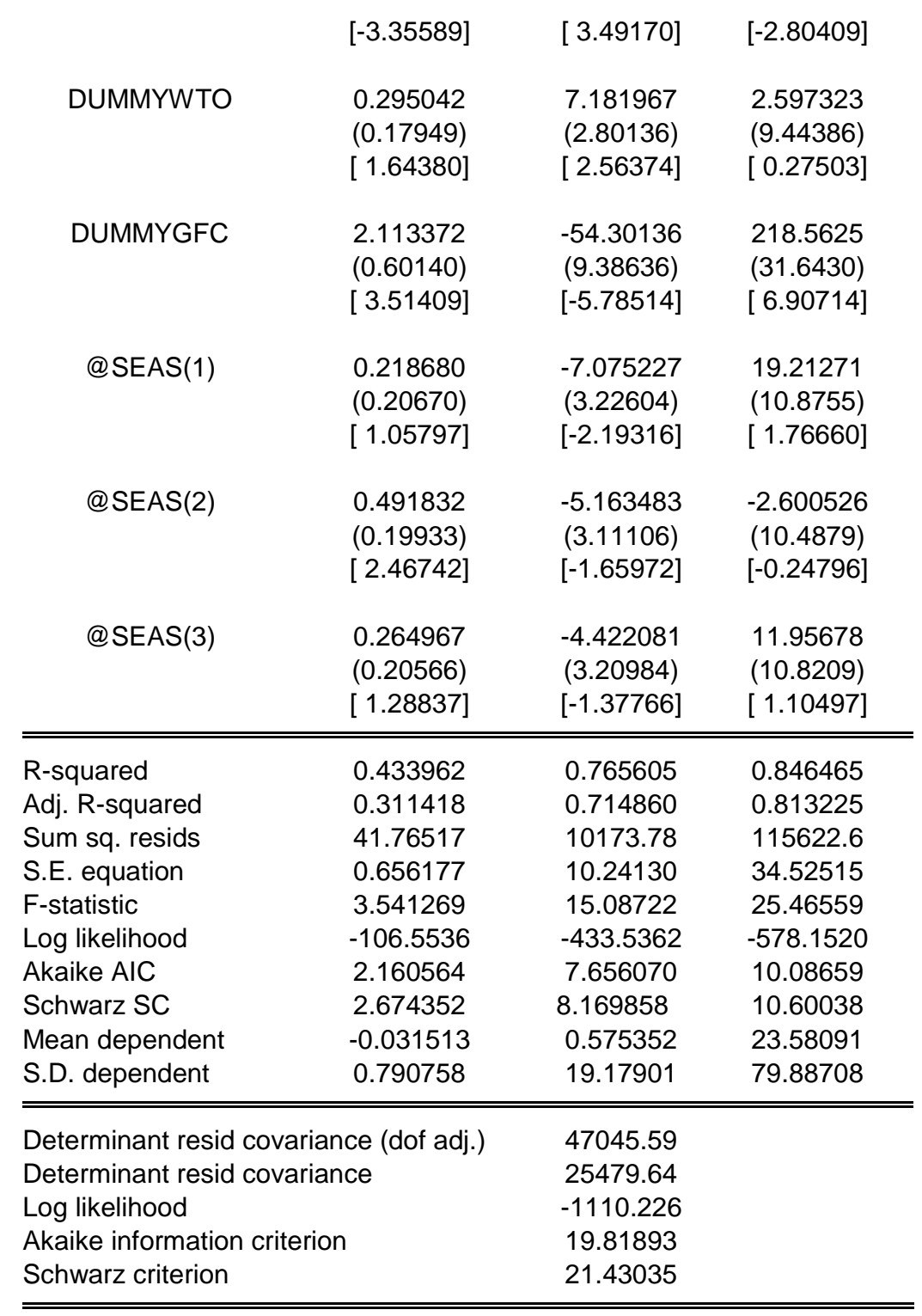


Editor, UWA Economics Discussion Papers:

Ernst Juerg Weber

Business School - Economics

University of Western Australia

35 Sterling Hwy

Crawley WA 6009

Australia

Email: ecoadmin@biz.uwa.edu.au

The Economics Discussion Papers are available at:

1980 - 2002: http://ecompapers.biz.uwa.edu.au/paper/PDF\%20of\%20Discussion\%20Papers/

Since 2001: http://ideas.repec.org/s/uwa/wpaper1.html

Since 2004: http://www.business.uwa.edu.au/school/disciplines/economics

\section{ECONOMICS DISCUSSION PAPERS}

2012

\begin{tabular}{|c|c|c|}
\hline $\begin{array}{l}\text { DP } \\
\text { NUMBER }\end{array}$ & AUTHORS & TITLE \\
\hline 12.01 & $\begin{array}{l}\text { Clements, K.W., Gao, G., and } \\
\text { Simpson, T. }\end{array}$ & $\begin{array}{l}\text { DISPARITIES IN INCOMES AND PRICES } \\
\text { INTERNATIONALLY }\end{array}$ \\
\hline 12.02 & Tyers, R. & $\begin{array}{l}\text { THE RISE AND ROBUSTNESS OF ECONOMIC FREEDOM } \\
\text { IN CHINA }\end{array}$ \\
\hline 12.03 & Golley, J. and Tyers, R. & $\begin{array}{l}\text { DEMOGRAPHIC DIVIDENDS, DEPENDENCIES AND } \\
\text { ECONOMIC GROWTH IN CHINA AND INDIA }\end{array}$ \\
\hline 12.04 & Tyers, R. & LOOKING INWARD FOR GROWTH \\
\hline 12.05 & Knight, K. and McLure, M. & THE ELUSIVE ARTHUR PIGOU \\
\hline 12.06 & McLure, M. & $\begin{array}{l}\text { ONE HUNDRED YEARS FROM TODAY: A. C. PIGOU'S } \\
\text { WEALTH AND WELFARE }\end{array}$ \\
\hline 12.07 & Khuu, A. and Weber, E.J. & HOW AUSTRALIAN FARMERS DEAL WITH RISK \\
\hline 12.08 & Chen, M. and Clements, K.W. & PATTERNS IN WORLD METALS PRICES \\
\hline 12.09 & Clements, K.W. & UWA ECONOMICS HONOURS \\
\hline 12.10 & Golley, J. and Tyers, R. & $\begin{array}{l}\text { CHINA'S GENDER IMBALANCE AND ITS ECONOMIC } \\
\text { PERFORMANCE }\end{array}$ \\
\hline 12.11 & Weber, E.J. & $\begin{array}{l}\text { AUSTRALIAN FISCAL POLICY IN THE AFTERMATH OF } \\
\text { THE GLOBAL FINANCIAL CRISIS }\end{array}$ \\
\hline 12.12 & Hartley, P.R. and Medlock III, K.B. & $\begin{array}{l}\text { CHANGES IN THE OPERATIONAL EFFICIENCY OF } \\
\text { NATIONAL OIL COMPANIES }\end{array}$ \\
\hline 12.13 & Li, L. & $\begin{array}{l}\text { HOW MUCH ARE RESOURCE PROJECTS WORTH? A } \\
\text { CAPITAL MARKET PERSPECTIVE }\end{array}$ \\
\hline 12.14 & Chen, A. and Groenewold, N. & $\begin{array}{l}\text { THE REGIONAL ECONOMIC EFFECTS OF A } \\
\text { REDUCTION IN CARBON EMISSIONS AND AN } \\
\text { EVALUATION OF OFFSETTING POLICIES IN CHINA }\end{array}$ \\
\hline 12.15 & Collins, J., Baer, B. and Weber, E.J. & $\begin{array}{l}\text { SEXUAL SELECTION, CONSPICUOUS CONSUMPTION } \\
\text { AND ECONOMIC GROWTH }\end{array}$ \\
\hline
\end{tabular}




\begin{tabular}{|c|c|c|}
\hline \multicolumn{3}{|c|}{$\begin{array}{l}\text { ECONOMICS DISCUSSION PAPERS } \\
2012\end{array}$} \\
\hline $\begin{array}{l}\text { DP } \\
\text { NUMBER }\end{array}$ & AUTHORS & TITLE \\
\hline 12.16 & Wu, Y. & TRENDS AND PROSPECTS IN CHINA'S R\&D SECTOR \\
\hline 12.17 & Cheong, T.S. and Wu, Y. & $\begin{array}{l}\text { INTRA-PROVINCIAL INEQUALITY IN CHINA: AN } \\
\text { ANALYSIS OF COUNTY-LEVEL DATA }\end{array}$ \\
\hline 12.18 & Cheong, T.S. & THE PATTERNS OF REGIONAL INEQUALITY IN CHINA \\
\hline 12.19 & Wu, Y. & $\begin{array}{l}\text { ELECTRICITY MARKET INTEGRATION: GLOBAL } \\
\text { TRENDS AND IMPLICATIONS FOR THE EAS REGION }\end{array}$ \\
\hline 12.20 & Knight, K. & $\begin{array}{l}\text { EXEGESIS OF DIGITAL TEXT FROM THE HISTORY OF } \\
\text { ECONOMIC THOUGHT: A COMPARATIVE } \\
\text { EXPLORATORY TEST }\end{array}$ \\
\hline 12.21 & Chatterjee, I. & $\begin{array}{l}\text { COSTLY REPORTING, EX-POST MONITORING, AND } \\
\text { COMMERCIAL PIRACY: A GAME THEORETIC } \\
\text { ANALYSIS }\end{array}$ \\
\hline 12.22 & Pen, S.E. & QUALITY-CONSTANT ILLICIT DRUG PRICES \\
\hline 12.23 & Cheong, T.S. and Wu, Y. & $\begin{array}{l}\text { REGIONAL DISPARITY, TRANSITIONAL DYNAMICS } \\
\text { AND CONVERGENCE IN CHINA }\end{array}$ \\
\hline 12.24 & Ezzati, P. & $\begin{array}{l}\text { FINANCIAL MARKETS INTEGRATION OF IRAN } \\
\text { WITHIN THE MIDDLE EAST AND WITH THE REST OF } \\
\text { THE WORLD }\end{array}$ \\
\hline 12.25 & Kwan, F., Wu, Y. and Zhuo, S. & $\begin{array}{l}\text { RE-EXAMINATION OF THE SURPLUS AGRICULTURAL } \\
\text { LABOUR IN CHINA }\end{array}$ \\
\hline 12.26 & Wu, Y. & R\&D BEHAVIOUR IN CHINESE FIRMS \\
\hline 12.27 & Tang, S.H.K. and Yung, L.C.W. & $\begin{array}{l}\text { MAIDS OR MENTORS? THE EFFECTS OF LIVE-IN } \\
\text { FOREIGN DOMESTIC WORKERS ON SCHOOL } \\
\text { CHILDREN'S EDUCATIONAL ACHIEVEMENT IN HONG } \\
\text { KONG }\end{array}$ \\
\hline 12.28 & Groenewold, N. & $\begin{array}{l}\text { AUSTRALIA AND THE GFC: SAVED BY ASTUTE } \\
\text { FISCAL POLICY? }\end{array}$ \\
\hline
\end{tabular}




\section{ECONOMICS DISCUSSION PAPERS}

2013

\begin{tabular}{|c|c|c|}
\hline $\begin{array}{l}\text { DP } \\
\text { NUMBER }\end{array}$ & AUTHORS & TITLE \\
\hline 13.01 & $\begin{array}{l}\text { Chen, M., Clements, K.W. and } \\
\text { Gao, G. }\end{array}$ & THREE FACTS ABOUT WORLD METAL PRICES \\
\hline 13.02 & Collins, J. and Richards, O. & $\begin{array}{l}\text { EVOLUTION, FERTILITY AND THE AGEING } \\
\text { POPULATION }\end{array}$ \\
\hline 13.03 & $\begin{array}{l}\text { Clements, K., Genberg, H., } \\
\text { Harberger, A., Lothian, J., } \\
\text { Mundell, R., Sonnenschein, H. and } \\
\text { Tolley, G. }\end{array}$ & LARRY SJAASTAD, 1934-2012 \\
\hline 13.04 & Robitaille, M.C. and Chatterjee, I. & MOTHERS-IN-LAW AND SON PREFERENCE IN INDIA \\
\hline 13.05 & Clements, K.W. and Izan, I.H.Y. & $\begin{array}{l}\text { REPORT ON THE } 25^{\mathrm{TH}} \text { PHD CONFERENCE IN } \\
\text { ECONOMICS AND BUSINESS }\end{array}$ \\
\hline 13.06 & Walker, A. and Tyers, R. & QUANTIFYING AUSTRALIA’S “THREE SPEED” BOOM \\
\hline 13.07 & Yu, F. and Wu, Y. & PATENT EXAMINATION AND DISGUISED PROTECTION \\
\hline 13.08 & Yu, F. and Wu, Y. & $\begin{array}{l}\text { PATENT CITATIONS AND KNOWLEDGE SPILLOVERS: } \\
\text { AN ANALYSIS OF CHINESE PATENTS REGISTER IN } \\
\text { THE US }\end{array}$ \\
\hline 13.09 & Chatterjee, I. and Saha, B. & BARGAINING DELEGATION IN MONOPOLY \\
\hline 13.10 & Cheong, T.S. and Wu, Y. & $\begin{array}{l}\text { GLOBALIZATION AND REGIONAL INEQUALITY IN } \\
\text { CHINA }\end{array}$ \\
\hline 13.11 & Cheong, T.S. and $\mathrm{Wu}, \mathrm{Y}$. & INEQUALITY AND CRIME RATES IN CHINA \\
\hline 13.12 & Robertson, P.E. and Ye, L. & ON THE EXISTENCE OF A MIDDLE INCOME TRAP \\
\hline 13.13 & Robertson, P.E. & THE GLOBAL IMPACT OF CHINA’S GROWTH \\
\hline 13.14 & $\begin{array}{l}\text { Hanaki, N., Jacquemet, N., } \\
\text { Luchini, S., and Zylbersztejn, A. }\end{array}$ & $\begin{array}{l}\text { BOUNDED RATIONALITY AND STRATEGIC } \\
\text { UNCERTAINTY IN A SIMPLE DOMINANCE SOLVABLE } \\
\text { GAME }\end{array}$ \\
\hline 13.15 & $\begin{array}{l}\text { Okatch, Z., Siddique, A. and } \\
\text { Rammohan, A. }\end{array}$ & $\begin{array}{l}\text { DETERMINANTS OF INCOME INEQUALITY IN } \\
\text { BOTSWANA }\end{array}$ \\
\hline 13.16 & Clements, K.W. and Gao, G. & $\begin{array}{l}\text { A MULTI-MARKET APPROACH TO MEASURING THE } \\
\text { CYCLE }\end{array}$ \\
\hline 13.17 & Chatterjee, I. and Ray, R. & $\begin{array}{l}\text { THE ROLE OF INSTITUTIONS IN THE INCIDENCE OF } \\
\text { CRIME AND CORRUPTION }\end{array}$ \\
\hline 13.18 & Fu, D. and Wu, Y. & $\begin{array}{l}\text { EXPORT SURVIVAL PATTERN AND DETERMINANTS } \\
\text { OF CHINESE MANUFACTURING FIRMS }\end{array}$ \\
\hline 13.19 & Shi, X., Wu, Y. and Zhao, D. & $\begin{array}{l}\text { KNOWLEDGE INTENSIVE BUSINESS SERVICES AND } \\
\text { THEIR IMPACT ON INNOVATION IN CHINA }\end{array}$ \\
\hline 13.20 & $\begin{array}{l}\text { Tyers, R., Zhang, Y. and } \\
\text { Cheong, T.S. }\end{array}$ & $\begin{array}{l}\text { CHINA'S SAVING AND GLOBAL ECONOMIC } \\
\text { PERFORMANCE }\end{array}$ \\
\hline 13.21 & Collins, J., Baer, B. and Weber, E.J. & $\begin{array}{l}\text { POPULATION, TECHNOLOGICAL PROGRESS AND THE } \\
\text { EVOLUTION OF INNOVATIVE POTENTIAL }\end{array}$ \\
\hline 13.22 & Hartley, P.R. & THE FUTURE OF LONG-TERM LNG CONTRACTS \\
\hline 13.23 & Tyers, R. & $\begin{array}{l}\text { A SIMPLE MODEL TO STUDY GLOBAL } \\
\text { MACROECONOMIC INTERDEPENDENCE }\end{array}$ \\
\hline
\end{tabular}




\begin{tabular}{|c|c|c|}
\hline \multicolumn{3}{|c|}{$\begin{array}{l}\text { ECONOMICS DISCUSSION PAPERS } \\
2013\end{array}$} \\
\hline $\begin{array}{l}\text { DP } \\
\text { NUMBER }\end{array}$ & AUTHORS & TITLE \\
\hline 13.24 & McLure, M. & $\begin{array}{l}\text { REFLECTIONS ON THE QUANTITY THEORY: PIGOU IN } \\
1917 \text { AND PARETO IN 1920-21 }\end{array}$ \\
\hline 13.25 & Chen, A. and Groenewold, N. & $\begin{array}{l}\text { REGIONAL EFFECTS OF AN EMISSIONS-REDUCTION } \\
\text { POLICY IN CHINA: THE IMPORTANCE OF THE } \\
\text { GOVERNMENT FINANCING METHOD }\end{array}$ \\
\hline 13.26 & Siddique, M.A.B. & $\begin{array}{l}\text { TRADE RELATIONS BETWEEN AUSTRALIA AND } \\
\text { THAILAND: } 1990 \text { TO } 2011\end{array}$ \\
\hline 13.27 & Li, B. and Zhang, J. & $\begin{array}{l}\text { GOVERNMENT DEBT IN AN INTERGENERATIONAL } \\
\text { MODEL OF ECONOMIC GROWTH, ENDOGENOUS } \\
\text { FERTILITY, AND ELASTIC LABOR WITH AN } \\
\text { APPLICATION TO JAPAN }\end{array}$ \\
\hline 13.28 & Robitaille, M. and Chatterjee, I. & $\begin{array}{l}\text { SEX-SELECTIVE ABORTIONS AND INFANT } \\
\text { MORTALITY IN INDIA: THE ROLE OF PARENTS' } \\
\text { STATED SON PREFERENCE }\end{array}$ \\
\hline 13.29 & Ezzati, P. & $\begin{array}{l}\text { ANALYSIS OF VOLATILITY SPILLOVER EFFECTS: } \\
\text { TWO-STAGE PROCEDURE BASED ON A MODIFIED } \\
\text { GARCH-M }\end{array}$ \\
\hline 13.30 & Robertson, P. E. & $\begin{array}{l}\text { DOES A FREE MARKET ECONOMY MAKE AUSTRALIA } \\
\text { MORE OR LESS SECURE IN A GLOBALISED WORLD? }\end{array}$ \\
\hline 13.31 & $\begin{array}{l}\text { Das, S., Ghate, C. and } \\
\text { Robertson, P. E. }\end{array}$ & $\begin{array}{l}\text { REMOTENESS AND UNBALANCED GROWTH: } \\
\text { UNDERSTANDING DIVERGENCE ACROSS INDIAN } \\
\text { DISTRICTS }\end{array}$ \\
\hline 13.32 & Robertson, P.E. and Sin, A. & $\begin{array}{l}\text { MEASURING HARD POWER: CHINA'S ECONOMIC } \\
\text { GROWTH AND MILITARY CAPACITY }\end{array}$ \\
\hline 13.33 & $\mathrm{Wu}, \mathrm{Y}$. & $\begin{array}{l}\text { TRENDS AND PROSPECTS FOR THE RENEWABLE } \\
\text { ENERGY SECTOR IN THE EAS REGION }\end{array}$ \\
\hline 13.34 & $\begin{array}{l}\text { Yang, S., Zhao, D., Wu, Y. and } \\
\text { Fan, J. }\end{array}$ & $\begin{array}{l}\text { REGIONAL VARIATION IN CARBON EMISSION AND } \\
\text { ITS DRIVING FORCES IN CHINA: AN INDEX } \\
\text { DECOMPOSITION ANALYSIS }\end{array}$ \\
\hline
\end{tabular}


ECONOMICS DISCUSSION PAPERS

2014

\begin{tabular}{|c|c|c|}
\hline $\begin{array}{l}\text { DP } \\
\text { NUMBER }\end{array}$ & AUTHORS & TITLE \\
\hline 14.01 & $\begin{array}{l}\text { Boediono, Vice President of the Republic } \\
\text { of Indonesia }\end{array}$ & $\begin{array}{l}\text { THE CHALLENGES OF POLICY MAKING IN A } \\
\text { YOUNG DEMOCRACY: THE CASE OF INDONESIA } \\
\text { (52ND SHANN MEMORIAL LECTURE, 2013) }\end{array}$ \\
\hline 14.02 & Metaxas, P.E. and Weber, E.J. & $\begin{array}{l}\text { AN AUSTRALIAN CONTRIBUTION TO } \\
\text { INTERNATIONAL TRADE THEORY: THE } \\
\text { DEPENDENT ECONOMY MODEL }\end{array}$ \\
\hline 14.03 & Fan, J., Zhao, D., Wu, Y. and Wei, J. & $\begin{array}{l}\text { CARBON PRICING AND ELECTRICITY MARKET } \\
\text { REFORMS IN CHINA }\end{array}$ \\
\hline 14.04 & McLure, M. & $\begin{array}{l}\text { A.C. PIGOU'S MEMBERSHIP OF THE } \\
\text { 'CHAMBERLAIN-BRADBURY’ COMMITTEE. } \\
\text { PART I: THE HISTORICAL CONTEXT }\end{array}$ \\
\hline 14.05 & McLure, M. & $\begin{array}{l}\text { A.C. PIGOU’S MEMBERSHIP OF THE } \\
\text { ‘CHAMBERLAIN-BRADBURY’ COMMITTEE. } \\
\text { PART II: ‘TRANSITIONAL’ AND ‘ONGOING’ ISSUES }\end{array}$ \\
\hline 14.06 & King, J.E. and McLure, M. & HISTORY OF THE CONCEPT OF VALUE \\
\hline 14.07 & Williams, A. & $\begin{array}{l}\text { A GLOBAL INDEX OF INFORMATION AND } \\
\text { POLITICAL TRANSPARENCY }\end{array}$ \\
\hline 14.08 & Knight, K. & $\begin{array}{l}\text { A.C. PIGOU'S THE THEORY OF UNEMPLOYMENT } \\
\text { AND ITS CORRIGENDA: THE LETTERS OF } \\
\text { MAURICE ALLEN, ARTHUR L. BOWLEY, RICHARD } \\
\text { KAHN AND DENNIS ROBERTSON }\end{array}$ \\
\hline 14.09 & Cheong, T.S. and $\mathrm{Wu}, \mathrm{Y}$. & $\begin{array}{l}\text { THE IMPACTS OF STRUCTURAL RANSFORMATION } \\
\text { AND INDUSTRIAL UPGRADING ON REGIONAL } \\
\text { INEQUALITY IN CHINA }\end{array}$ \\
\hline 14.10 & $\begin{array}{l}\text { Chowdhury, M.H., Dewan, M.N.A., } \\
\text { Quaddus, M., Naude, M. and } \\
\text { Siddique, A. }\end{array}$ & $\begin{array}{l}\text { GENDER EQUALITY AND SUSTAINABLE } \\
\text { DEVELOPMENT WITH A FOCUS ON THE COASTAL } \\
\text { FISHING COMMUNITY OF BANGLADESH }\end{array}$ \\
\hline 14.11 & Bon, J. & $\begin{array}{l}\text { UWA DISCUSSION PAPERS IN ECONOMICS: THE } \\
\text { FIRST } 750\end{array}$ \\
\hline 14.12 & Finlay, K. and Magnusson, L.M. & $\begin{array}{l}\text { BOOTSTRAP METHODS FOR INFERENCE WITH } \\
\text { CLUSTER-SAMPLE IV MODELS }\end{array}$ \\
\hline 14.13 & Chen, A. and Groenewold, N. & $\begin{array}{l}\text { THE EFFECTS OF MACROECONOMIC SHOCKS ON } \\
\text { THE DISTRIBUTION OF PROVINCIAL OUTPUT IN } \\
\text { CHINA: ESTIMATES FROM A RESTRICTED VAR } \\
\text { MODEL }\end{array}$ \\
\hline 14.14 & Hartley, P.R. and Medlock III, K.B. & $\begin{array}{l}\text { THE VALLEY OF DEATH FOR NEW ENERGY } \\
\text { TECHNOLOGIES }\end{array}$ \\
\hline 14.15 & $\begin{array}{l}\text { Hartley, P.R., Medlock III, K.B., } \\
\text { Temzelides, T. and Zhang, X. }\end{array}$ & $\begin{array}{l}\text { LOCAL EMPLOYMENT IMPACT FROM COMPETING } \\
\text { ENERGY SOURCES: SHALE GAS VERSUS WIND } \\
\text { GENERATION IN TEXAS }\end{array}$ \\
\hline 14.16 & Tyers, R. and Zhang, Y. & $\begin{array}{l}\text { SHORT RUN EFFECTS OF THE ECONOMIC REFORM } \\
\text { AGENDA }\end{array}$ \\
\hline 14.17 & Clements, K.W., Si, J. and Simpson, T. & UNDERSTANDING NEW RESOURCE PROJECTS \\
\hline 14.18 & Tyers, R. & $\begin{array}{l}\text { SERVICE OLIGOPOLIES AND AUSTRALIA’S } \\
\text { ECONOMY-WIDE PERFORMANCE }\end{array}$ \\
\hline
\end{tabular}




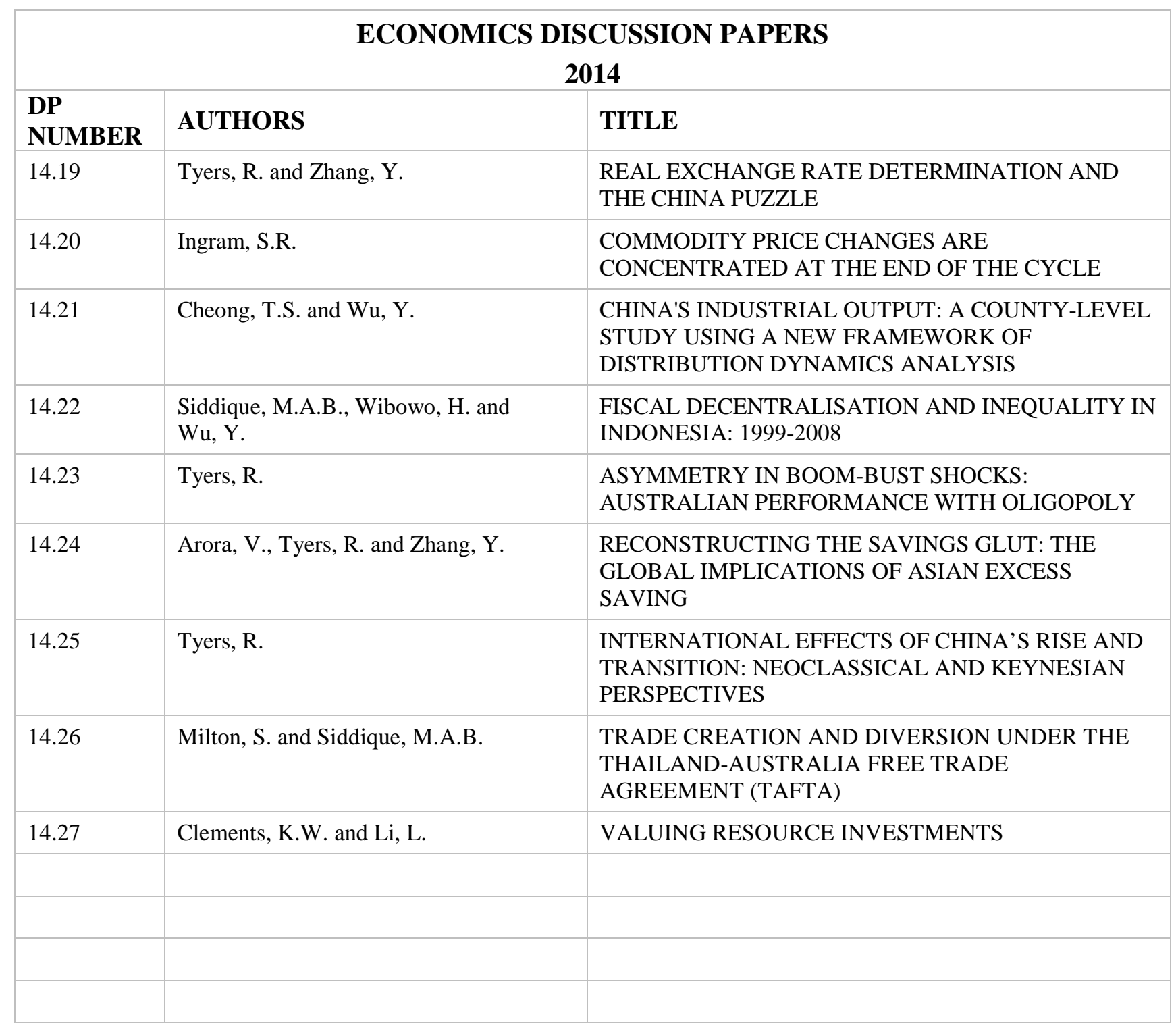

